\title{
Comunicação Triádica em Pediatria: Revisão de Literatura
}

\author{
Marina Kohlsdorf ${ }^{1}$ \\ Centro Universitário de Brasília - UniCeub, Brasília, DF, Brasil \\ Áderson Luiz Costa Junior \\ Departamento de Psicologia Clínica da Universidade de Brasília, Brasilia, DF, Brasil
}

\begin{abstract}
Resumo
A comunicação triádica em pediatria tem sido foco de pesquisa nos últimos 20 anos, considerando a relevância de compreender este processo para melhorar a assistência em saúde a crianças e adolescentes. Esta revisão sistemática de literatura teve como objetivo analisar 118 trabalhos sobre este tema, publicados entre 2000 e 2012. Os resultados mostram distribuição regular dos estudos ao longo do período, com prevalência de pesquisas em caráter descritivo e com metodologia quantitativa. A literatura enfatiza que a comunicação promove melhores níveis de adesão aos cuidados, melhoria de sintomas e respostas clínicas, comportamentos colaborativos e adaptação ao tratamento, contudo a focalização de habilidades comunicativas triádicas durante a graduação profissional é insuficiente. Destaca-se que a criança é excluída da interação e as demandas individuais por informação devem ser prioridade. São necessários mais estudos sobre intervenções psicossociais e em caráter longitudinal, que possam contribuir para a compreensão do processo de comunicação em pediatria.
\end{abstract}

Palavras-chave: Revisão de literatura, comunicação pediátrica, relação terapêutica.

\section{Triadic communication in Pediatrics: Literature review}

\begin{abstract}
Triadic communication in pediatrics has been focused in the last 20 years, considering the relevance of understanding this process in order to improve health assistance to children and adolescents. The main purpose of this systematic literature review was to analyze 118 papers related to this theme, published between 2000 and 2012. Results show a regular distribution of studies along this period, with prevalence of descriptive researches that included quantitative methodology. Literature emphasizes that communication promotes better adherence to healthcare, improvement in symptoms and clinical responses, collaborative behaviors and adaptation to treatment, however the focus on triadic communicative skills during graduation is not sufficient. The child is excluded from the interaction and tailored demands for information must be a priority. More studies are needed, concerning psychosocial interventions in longitudinal design, which may contribute to understand communicative processes in pediatric settings.
\end{abstract}

Keywords: Literature review, pediatric communication, therapeutic relationship.

Endereço para correspondência: SQS 103, bloco B, Apto. 101, Brasília, DF, Brasil 70342-020. Fax: (61) 32244452.E-mailmarinak@unb.bre aderson@unb.br 


\section{Comunicación Tríadica en Pediatría: Revisión de la Literatura}

\section{Resumen}

La comunicación triádica en pediatría ha sido un tema relevante de investigación en los últimos 20 años, considerándose la importancia de comprender ese proceso para mejorar los cuidados de la salud para niños y adolescentes. Esta revisión sistemática ha tenido como objetivo analizar 118 artículos sobre el tema publicados entre 2000 y 2012. Los resultados de los estudios presentan una distribución regular a lo largo del período, con una prevalencia de encuestas de carácter descriptivo y metodología cuantitativa. La literatura enfatiza que la comunicación promueve mejores niveles de adherencia a los cuidados de la salud, la mejora de los síntomas y de las respuestas clínicas, comportamientos colaborativos y la adaptación al tratamiento. Sin embargo, el foco en las habilidades de comunicación triádicas durante la formación académica de pregrado es insuficiente. Cabe señalar que el niño es excluido de la interacción y las demandas individuales de información deben ser una prioridad. Se necesitan más estudios sobre las intervenciones psicosociales y de carácter longitudinal que pueden contribuir a la comprensión del proceso de comunicación en pediatría.

Palabras clave: Revisión de la literatura, comunicación en pediatría, relación terapéutica.

A comunicação em saúde pode ser caracterizada como um processo relacional, embasado em fatores culturais e sócio-históricos, em que informações e sua compreensão são compartilhadas entre, pelo menos, duas pessoas, considerando que na assistência pediátrica este processo é caracterizado por uma interação em tríades médico-acompanhante-paciente (Aburn \& Gott, 2011; Gabe, Olumide, \& Bury, 2004; Howells, Davies, \& Silverman, 2006; Howells \& Lopez, 2008; McGraw et al., 2012; Nobile \& Drotar, 2003; Sobo, 2004; Tates \& Meeuwesen, 2001).

A comunicação entre médicos e pacientes deve promover comportamentos preventivos $\mathrm{e}$ adaptação ao tratamento e, por esta razão, vem se constituindo em um importante foco de pesquisas nas duas últimas décadas (Conboy et al., 2010; Coyne, 2008; Kreps, Bonaguro, \& Query, 1998; Ong, Haes, Hoos, \& Lammes, 1995). A interação médico-paciente influencia a compreensão do diagnóstico e vivência do tratamento, com consequências diretas sobre a satisfação com o atendimento, adesão aos cuidados, recordação e compreensão sobre recomendações, melhoria de respostas fisiológicas e sintomas, manejo de eventos estressores, melhor satisfação com suporte social e adaptação ao planejamento terapêutico (Caprara \&
Rodrigues, 2004; Conboy et al., 2010; Coyne \& Harder, 2011; DiMatteo, 2003, 2004; Patistea \& Babatsikou, 2003; Varni, Quiggins, \& Ayala, 2000; S. Young \& Oppenheimer, 2009; Zolnierek \& DiMatteo, 2009). Deste modo, a compreensão mais sistemática da comunicação em contextos de assistência pediátrica, a partir da análise de trabalhos publicados recentemente pode apontar como lidar com sistemas mais eficientes de interação, otimizando a informação e sua utilização ao longo do tratamento e dos cuidados com a saúde em geral.

Estudos revelam que crianças por volta dos quatro anos já possuem potencial para compreenderem informações sobre autocuidados, identificam sintomas e órgãos afetados por doenças, têm dúvidas, mencionam comportamentos promotores de saúde e descrevem implicações emocionais vivenciadas durante um tratamento, aspectos que guardam relação com idade, história de contato com doenças, contexto socioeconômico e informações recebidas, porém, pode haver culpabilização pelo adoecimento (Buckley \& Savage, 2010; Gabarra \& Crepaldi, 2011; Gordon et al., 2010; Knighting, Rowa-Dewar, Malcolm, Kearney, \& Gibson, 2010; Koopman, Baars, Chaplin, \& Zwinderman, 2004; Märtenson \& Fägerskiöld, 2007; Märtenson, 
Fägerskiöld, \& Berteró, 2007; Nova, Vegni, \& Moja, 2005; Outsubo \& Becker, 2005; Perosa \& Gabarra, 2004; Vatne, Slaughter, \& Ruland, 2010). Estes dados enfatizam a necessidade de comunicação com a criança subsidiada por uma exploração desta interação triádica durante a formação de graduação médica, com adaptações por parte dos pediatras expostos a contextos específicos de cuidados pediátricos.

Estudos conduzidos por Barbara Korsch e colaboradores, na década de 1960, foram pioneiros na avaliação sobre a comunicação no contexto pediátrico (Nobile \& Drotar, 2003). Em um destes trabalhos, Korsch, Gozzi e Francis (1968) já destacavam a necessidade de ampliar a compreensão sobre comunicação em pediatria para além de bases intuitivas, incluindo a investigação objetiva e sistemática dos fatores envolvidos. Constituiu objetivo deste estudo analisar sistematicamente a literatura sobre comunicação triádica em contextos de assistência pediátrica, incluindo trabalhos publicados entre 2000 e 2012.

\section{Método}

Para esta revisão sistemática de literatura, foram incluídos materiais disponibilizados nas bases de dados OVID, PsycInfo, EBSCOhost, SAGE, SpringerLink, Elsevier ScienceDirect, além de busca complementar em 98 revistas disponibilizadas no Portal de Periódicos da Coordenação de Aperfeiçoamento de Pessoal de Nível Superior (CAPES). As palavras-chave utilizadas incluíram communication, consultation, information, interaction e suas variações, combinadas, quando relevante, aos termos child, pediatric, parent, physician, doctor e suas variações. Os termos correspondentes na língua portuguesa foram empregados para levantamento em revistas disponíveis na Scientific Electronic Library Online (SciELO).

Critérios para seleção de estudos incluíram a comunicação envolvendo o médico e/ou médico residente em contexto de atendimento a cuidadores de crianças e/ou crianças diretamente. Estudos relacionados à comunicação de diagnóstico ou cuidados paliativos não foram incluídos por constituírem contextos peculiares que demandam habilidades muito específicas. De forma análoga, não foram incluídos trabalhos relacionados a condições que exigem um padrão de interação diferenciado: (a) crianças com atrasos de desenvolvimento, deficiência cognitiva ou portadoras de dificuldades comunicativas; (b) estudos sobre consentimento para participação em ensaios clínicos; (c) comunicação sobre medicina complementar alternativa; (d) comunicação online ou mediada pela rede mundial de computadores (Internet); (e) trabalhos focalizados na adaptação a outros idiomas proferidos por médicos e usuários. Foram selecionados ao todo 118 trabalhos, sendo dez estudos nacionais, que corresponderam aos critérios estabelecidos. Detalhes metodológicos destes estudos estão disponíveis no anexo.

\section{Resultados}

Observou-se uma distribuição regular dos trabalhos entre 2012 e 2000, com média de nove estudos por ano, constituídos por 92 artigos publicados em periódicos científicos e quatro dissertações nacionais de mestrado. A maioria dos estudos correspondeu a delineamentos descritivos $(n=74)$, porém, houve pesquisas em caráter experimental ou semi-experimental $(n=12)$ e construção ou validação de questionários padronizados sobre comunicação $(n=10)$. Houve predominância de métodos quantitativos $(n=55)$ e qualitativos $(n=21)$ em detrimento de análises mistas $(n=20)$. As técnicas de coleta de dados incluíram gravações em áudio e vídeo, entrevistas, questionários, workshops, role play, observação presencial de consultas e grupos focais. Entre os trabalhos, somente 26 incluíram também pacientes adolescentes (acima de 12 anos de idade) e apenas o artigo de Oliveira e Gomes (2004) focalizou exclusivamente adolescentes em sua amostra. Desta forma, as análises apresentadas no presente estudo são concentradas na comunicação triádica com crianças. Os principais resultados destacados na literatura analisada são descritos a seguir. 
Efeitos da Comunicação sobre a Vivência da Tríade Cuidadores-Pacientes-Profissionais

O tempo de atendimento, em consulta, aumentou nos últimos 20 anos e permaneceu circunscrito entre sete e 29 minutos (Blumberg \& O'Connor, 2004; Clark et al., 2000; Pinto, 2010; Silva, 2000; Sleath et al., 2011; Tates \& Meeuwesen, 2000; Tates, Meeuwesen, Bensing, \& Elbers, 2002; Vatne, Finset, Ornes, \& Ruland, 2010). Contudo, a duração da consulta não deve ser exclusivamente apontada como preditora de comunicação eficiente nem de satisfação com a interação (Goore, Mangione-Smith, Elliott, McDonald, \& Kravitz, 2001).

As informações referidas pelo médico influenciam a satisfação dos usuários com o serviço e qualidade geral da saúde (Darby, 2002; Fiks, Localio, Alessandrini, Asch, \& Guevara, 2010; Fisher \& Broome, 2011; Galil et al., 2006; Liu, Harris, Keyton, \& Frankel, 2007; Sleath et al., 2012; Swedlund, Schumacher, Young, \& Cox, 2012). De modo geral, os serviços de saúde têm sido bem avaliados pelos cuidadores (Hart, Kelleher, Drotar, \& Scholle, 2007; McGraw et al., 2012; B. Young, Ward, Forsey, Gravenhorst, \& Salmon, 2011a). Há necessidade de uma atuação individualizada, que considere demandas, interesses e nível de compreensão dos usuários, pois, a despeito da satisfação com a comunicação, as informações fornecidas não garantem uma compreensão efetiva e podem ser ineficientes à manutenção de cuidados (Clarke \& Fletcher, 2003; Drotar, 2009; Goore et al., 2001; Mendonça, 2007; Patistea \& Babatsikou, 2003; Pinto, 2010).

Além da satisfação de usuários, a comunicação influencia níveis de adesão, sintomas e respostas clínicas, compreensão sobre diagnóstico e tratamento, melhor manejo de fatores psicossociais, melhor recordação das explicações e menos retornos ambulatoriais (Ammentorp, Kofoed, \& Laulund, 2011; Clark et al., 2000; Cohen \& Wambolt, 2000; Coyne \& Gallagher, 2011; Croom et al., 2011; Crossley \& Davies, 2005; DiMatteo, 2004; Drotar, 2009; Nobile \& Drotar, 2003; Scrimin et al., 2005; Sleath et al.,
2012). Alguns estudos enfatizam que a qualidade da interação também propicia melhor qualidade de vida, melhor manejo de ansiedade e mais comportamentos colaborativos ao tratamento (Gordon et al., 2010; Sharma, Prematta, \& Fausnight, 2012; Wissow et al., 2012).

Cabe destacar que a satisfação de cuidadores e pacientes com a comunicação implica melhorias para os pediatras, ao promover: (a) confiança dos usuários no médico; (b) provisão de mais informações aos pediatras; (c) alívio das sobrecargas psicossociais; (d) melhor compreensão e recordação das orientações; (e) diminuição da sobrecarga de trabalho (Howells \& Lopez, 2008; Nobile \& Drotar, 2003). A literatura também enfatiza que dificuldades de comunicação em contexto pediátrico muitas vezes são promovidas pela organização do atendimento, como condições no ambiente de espera pela consulta, excessivo número de pacientes, tempo reduzido para atendimento e longo tempo de espera (Cruz-Hernández, 2004; Gabe et al., 2004; Pinto, 2010; Ringnér, Jansson, \& Graneheim, 2010; Wissow \& Kimel, 2002).

Alguns comportamentos dos médicos têm sido destacados como desejáveis à interação: (a) habilidades clínicas de diagnóstico e aptidões técnicas; (b) capacidade de interação psicossocial; (c) qualidade das explicações, informações detalhadas e uso de linguagem acessível; (d) promoção de suporte social e acolhimento a demandas emocionais; (e) centralização no paciente e cuidador (Fisher \& Broome, 2011; Périco, Grosseman, Robles, \& Stoll, 2006). Outros elementos relevantes incluem a disponibilidade de tempo para perguntas, identificação de pais e pacientes pelo nome próprio e estabelecimento de vínculo colaborativo (Crossley, Eiser, \& Davies, 2005; Hammond \& McLean, 2009; Hart et al., 2007; Scrimin et al., 2005).

Dados sociodemográficos dos cuidadores e história profissional dos médicos têm sido associados à quantidade e qualidade das informações providas: quanto mais anos de prática médica e quanto maior a renda e escolaridade dos cuidadores, maior a provisão de informações pelos médicos (Brinkman et al., 2011; Miller, Drotar, Burant, \& Kodish, 2005; Moseley, 
Clark, Gebremariam, Sternthal, \& Kemper, 2006; Taylor, Haase-Casanovas, Weaver, Kidd, \& Garralda, 2010; Washington et al., 2012; Zwaanswijk et al., 2007).

\section{Participação Infantil na Comunicação Triádica}

A literatura sinaliza que a interação em contexto pediátrico exclui a criança da comunicação. Embora a participação do paciente nas consultas venha aumentando ao longo dos últimos 20 anos, de modo geral, é estabelecido um contexto em que a criança participa apenas como provedora de informações básicas ou com interações distrativas durante o exame físico, pois orientações são direcionadas aos pais (Armelin, Wallau, Sarti, \& Pereira, 2005; Cahill \& Papageorgiou, 2007a; Gabarra \& Crepaldi, 2011; Mangione-Smith et al., 2001; Nobile \& Drotar, 2003; Oliveira \& Gomes, 2004; Rotenberg et al., 2008; Scrimin et al., 2005; Tates \& Meeuwesen, 2000, 2001; Tates, Elbers, Meeuwesen, \& Bensing, 2002; Tates, Meeuwesen, Elbers, \& Bensing, 2002; Vaknin, \& Zisk-Rony, 2010; van Dulmen, 2004; van Dulmen \& Holl, 2000).

Nas últimas décadas, houve aumento da participação dos pacientes na interação, porém, o médico ainda conduz a consulta e direciona as interações, sendo responsável, em grande parte, pelo padrão interativo estabelecido no atendimento. A participação do paciente corresponde a proporções entre $2 \%$ e $14 \%$ da interação (Nova et al., 2005; Tates \& Meeuwesen, 2000, 2001; Tates, Meeuwesen, Bensing, et al., 2002; Wassmer et al., 2004). Pais e médicos podem excluir o paciente da interação em decorrência de uma intenção protecionista à criança e os cuidadores podem mediar a interação com o médico ao responder perguntas inicialmente dirigidas ao paciente (Coyne \& Gallagher, 2011; Hallström, 2004; Ranzani, 2009; Tates, Elbers, et al., 2002; B. Young et al., 2010, 2011b). A gravidade da doença, a idade e escolaridade do paciente podem ser determinantes da interação: médicos e cuidadores tendem a se dirigir a crianças com mais idade, mais escolaridade e melhor prognóstico (Drotar, 2009; Gabarra \& Crepaldi, 2011; Kain et al., 2009; Perosa \& Ranzani, 2008; Stivers, 2001, 2012; Stivers \& Majid, 2007; Tates, Elbers, et al., 2002; Tates, Meeuwesen, Bensing, et al., 2002; Tates, Meeuwesen, Elbers, et al., 2002; Taylor et al., 2010).

\section{Inclusão de Temas Psicossociais na Interação e Preferências Individuais por Informação}

A comunicação provida pelos pediatras se caracteriza por interações de cunho biofisiológico, em detrimento a interações que estabeleçam vínculo, fundamentadas na empatia e acolhimento e que possam abordar temas psicossociais e/ou afetivo-emocionais (Wassmer et al., 2004). Contudo, a inclusão de temas psicossociais pode promover maiores índices de satisfação dos usuários, estabelecendo uma aliança terapêutica promotora de cuidados em saúde a partir de uma interação afetiva que promova perguntas de pais e pacientes (Blumberg \& O'Connor, 2004; Brown \& Wissow, 2008; Cohen \& Wamboldt, 2000; El Malla et al., 2013; Galil et al., 2006; Schuster, Duan, Regalado, \& Klein, 2000; Swedlund et al., 2012; Wassmer et al., 2004; Wissow, Brown, \& Krupnick, 2010).

O modelo biopsicossocial de atenção em saúde enfatiza o papel de profissionais como importante rede de suporte social e, assim, é possível destacar a relevância do estabelecimento de padrões psicossociais de comunicação no acompanhamento pediátrico como moderadores de adaptação ao tratamento (El Malla et al., 2013; Heneghan, Mercer, \& DeLeone, 2004; Kästel, Enskär, \& Björk, 2011; Kiguli, Mafigiri, Nakigudde, Dalen, \& Vleuten, 2011; Wissow et al., 2008). As preocupações dos cuidadores ultrapassam cuidados biofisiológicos em saúde: apreensões sobre a dinâmica familiar, dificuldades emocionais e psicossociais podem ser geradas em função da terapêutica e potencializar exigências deste contexto. Estes aspectos são moderadores da adaptação ao tratamento e sucesso terapêutico e, portanto, correspondem a elementos que devem ser abordados na interação comunicativa (Blumberg \& O'Connor, 2004; Schuster et al., 2000; van Dulmen, 2004). 
Destaca-se o papel preventivo e promotor de saúde do pediatra, pois o médico pode identificar precocemente fatores psicossociais moderadores do processo de saúde-doença, promovendo suporte social, indicando orientações básicas e/ou providenciando encaminhamentos (Coleman, 2002; Gabarra \& Crepaldi, 2011; Heneghan et al., 2004; Silva, 2000; Wissow et al., 2008). Especialmente em condições crônicas, o pediatra assiste pacientes e familiares por um período longo de tempo, acompanhando mudanças relevantes e se constituindo muitas vezes figura de referência aos cuidadores para aspectos além do escopo biomédico (Engelen et al., 2010; Wissow, Larson, Anderson, \& Hadjiisky, 2005).

A empatia, a atenção e acolhimento, o vínculo, a qualidade da relação emocional, a inserção de temas sobre condição familiar, contexto sociocultural, atividade lúdica, social e escolar da criança e dinâmica familiar constituem elementos fundamentais à comunicação triádica pediátrica (Cohen \& Wamboldt, 2000; Drotar, 2009; Mack, Wolfe, Grier, Cleary, \& Weeks, 2006; Silva, 2000). Médicos e cuidadores podem evitar incluir assuntos psicossociais pela crença de que são demasiadamente intrusivos, por não haver tempo ou por não terem preparo para lidar com tais temas (Brinkman et al., 2011; Brown \& Wissow, 2008; Hayutin, Reed-Knight, Blount, Lewis, \& McCormick, 2009; Schuster et al., 2000; Tates \& Meeuwesen, 2001; Wassmer et al., 2004; Wildman, Stancin, Golden, \& Yerkey, 2004; Wissow et al., 2005).

Outro aspecto destacado se refere às preferências individuais sobre quantidade e tipo de informação, relacionada a pressupostos da humanização (Deslandes, 2004; Gabarra \& Crepaldi, 2011; Goore et al., 2001; Howells \& Lopez, 2008; Mack et al., 2006). Os estudos apresentam a focalização de demandas individuais como elemento que facilita adaptação ao tratamento e satisfação dos usuários (Coyne \& Gallagher, 2011; Lambert, Glacken, \& McCarron, 2011; Nestel, Taylor, \& Spender, 2004; Ranzani, 2009; Ringnér et al., 2010; Zwaanswijk et al., 2011). Especificamente no caso de doenças crônicas pediátricas, momentos distintos do tratamento podem requerer informações específicas, corroborando a relevância da comunicação sob medida (Kästel et al., 2011).

\section{Preparação Acadêmica para a Comunicação em Contexto Pediátrico}

A formação durante a graduação não tem incluído aprofundamento satisfatório sobre a dinâmica das consultas pediátricas. Médicos enfatizam a importância de estudar habilidades comunicativas específicas em pediatria, porém, a abordagem deste conteúdo ao longo da graduação tem sido referida como insuficiente (Dubé, LaMonica, Boyle, Fuller, \& Burkholder, 2003; Nestel et al., 2004; Perosa \& Ranzani, 2008; Rider, Volkan, \& Hafler, 2008; Viegas, 2003). Intervenções breves, após o início da prática profissional, têm se mostrado promissoras ao ampliar o repertório de comportamentos interativos em contextos pediátricos (Ammentorp et al., 2011; Farrell, Ryan, \& Langrick, 2001; Felt \& O'Connor, 2003; Gough, Frydenberg, Donath, \& Marks, 2009; Hart, Drotar, Gori, \& Lewin, 2006; Kemper, Foy, Wissow, \& Shore, 2008; Nikendei et al., 2011; van Dulmen \& Holl, 2000).

Os procedimentos descritos nos estudos incluíram workshops breves, gravações em vídeo e role play (Farrell et al., 2001; van Dulmen \& Holl, 2000), além de palestras e grupos focais multidisciplinares (Ammentorp et al., 2011; Nikendei et al., 2011). Estas intervenções conduziram à ampliação do repertório comunicativo de médicos e cuidadores, incluindo melhor manejo de dificuldades psicossociais, percepção de auto-eficácia pelos médicos e satisfação dos pediatras com a comunicação (Farrell et al., 2001; Gough et al., 2009; Hart et al., 2006; Jirasevijinda \& Brown, 2010; Kemper et al., 2008; Nikendei et al., 2011; van Dulmen \& Holl, 2000). Alguns estudos destacam que intervenções com a equipe médica promoveram mais diálogo interdisciplinar, resultando em melhores condições de atendimento, além de promover maior satisfação de cuidadores e crianças (Ammentorp et al., 2011; Farrell et al., 2001; Gough et al., 2009; Harrington, Norling, Witte, Taylor, \& Andrews, 2007; Hart et al., 2006). 


\section{Discussão}

O estudo da comunicação na assistência pediátrica pode promover subsídios para intervenções psicossociais que promovam melhor adaptação ao tratamento. Destaca-se a relevância desta reflexão para formulação de mudanças curriculares nos cursos técnicos e de graduação que possam oferecer habilidades mais eficientes aos médicos.

Sendo a comunicação um processo dinâmico, são imprescindíveis estudos de acompanhamento que analisem as mudanças de interação ao longo do tempo, especialmente em contextos de tratamento pediátrico crônico (Cahill \& Papageorgiou, 2007b; Nobile \& Drotar, 2003; Tates, Elbers, et al., 2002). Este trabalho mostrou primazia de estudos descritivos e, portanto, aponta-se também a necessidade de estudos que investiguem intervenções sobre a comunicação, além de pesquisas sobre satisfação com a interação, incluindo elementos afetivo-emocionais e psicossociais na rotina de atendimento e a modificação na forma de abordar elementos biomédicos para além da linguagem técnica (Buckley \& Savage, 2010; Christakis, Johnston, \& Connell, 2001; Nobile \& Drotar, 2003; O'Keefe, 2001; Wildman et al., 2004).

Outro destaque se refere ao uso de instrumentos validados para codificar a interação comunicativa, entre os quais se destacam Roter Interaction Analysis System (Brown \& Krupnik, 2010; Cousino et al., 2011; Wissow et al., 2005), Verona Coding Definitions of Emotional Sequences (Vatne, Finset, et al., 2010), Five Minute Speech Sample (Cohen \& Wamboldt, 2000) e Paediatric Consultation Assessment Tool (Howells, Davies, Silverman, Archer, \& Mellon, 2010). Estes instrumentos permitem a observação direta da interação a partir de codificações com altos índices de confiabilidade, entretanto, podem descontextualizar a comunicação, pois avaliam a interação em elementos isolados e não sistêmicos, não incluem a análise de relações funcionais entre os comportamentos da tríade nem moderadores relacionados à organização do serviço de saúde.
Os estudos analisados sinalizam variáveis potencialmente favoráveis ao contexto de atendimento pediátrico, enfatizando temas fundamentais ao tratamento e assuntos para além da terapêutica que possam promover a atuação ativa de crianças e cuidadores. É possível sintetizar alguns destes aspectos, que são descritos a seguir.

Inicialmente, destaca-se que a comunicação em pediatria se caracteriza por uma interação triádica entre indivíduos em processo de desenvolvimento e, portanto, deve enfatizar o papel ativo de crianças, cuidadores e médicos na construção compartilhada da atenção à saúde, baseando-se nos pressupostos de humanização, direito do usuário à informação e participação social (Deslandes, 2004; Garrafa \& Albuquerque, 2001). Entretanto, os pediatras salientam a escassez de aprofundamento para atuação neste contexto comunicativo ao longo de sua graduação, aspecto que cria demandas para educação continuada em saúde ao longo da atuação profissional (Dubé et al., 2003; Nestel et al., 2004; Perosa \& Ranzani, 2008; Rider et al., 2008; Viegas, 2003).

Elementos relacionados à organização $\mathrm{e}$ funcionamento do serviço, bem como sistemas culturais e sociohistóricos, devem ser focalizados como moderadores importantes da comunicação, considerando que cada equipe de saúde possui características próprias que influenciam seus processos particulares de humanização (Deslandes, 2004; Silva, 2000). Ressalta-se a relevância da inclusão de aspectos psicossociais vivenciados no tratamento e de elementos relacionados à promoção de saúde (Wassmer et al., 2004). Este argumento destaca o papel desempenhado pelo pediatra como promotor de saúde global, prevenção de doenças e compreensão multifatorial do processo saúde-doença (Silva, 2000).

Concluindo, os estudos analisados propõem que a comunicação na assistência pediátrica: (a) enfatize a satisfação, sob medida, de necessidades individuais de cada participante; (b) promova a participação ativa de seus interlocutores; (c) englobe elementos biopsicossociais; (d) promova suporte social, vínculo colaborativo e aliança terapêutica; (e) facilite a compreensão 
coerente de cuidadores e crianças sobre recomendações de cuidados, planejamento terapêutico, fundamentos etiológicos em saúde-doença e demais temas associados ao tratamento. Tais medidas podem diminuir custos comportamentais da tríade associados aos cuidados, enfatizar a promoção de saúde e facilitar a adaptação ao tratamento. Destaca-se, portanto, que são necessárias revisões e ajustes nos currículos de graduação e formação em saúde que possam focalizar um modelo triádico de atuação que contemple estes objetivos, tendo em vista a complexidade e especificidades deste contexto comunicativo pediátrico.

\section{Referências}

Aburn, G., \& Gott, M. (2011). Education given to parents of children newly diagnosed with acute lymphoblastic leukemia: A narrative review. Journal of Pediatric Oncology Nursing, 28(5), 300-305. doi:10.1177/1043454211409585

Ammentorp, J., Kofoed, P. E., \& Laulund, L. W. (2011). Impact of communication skills training on parents perceptions of care: Intervention study. Journal of Advanced Nursing, 67(2), 394400. doi:10.1111/j.1365-2648.2010.05475.x

Armelin, C. B., Wallau, R. A., Sarti, C. A., \& Pereira, S. R. (2005). A comunicação entre os profissionais de pediatria e a criança hospitalizada. Revista Brasileira de Crescimento e Desenvolvimento Humano, 15(2), 45-54.

Blumberg, S. J., \& O'Connor, K. S. (2004). Parent's mood and the content of pediatric care for young children. Ambulatory Pediatrics, 4(3), 209-216. doi:10.1367/A03-127-R.1

Brinkman, W. B., Hartl, J., Rawe, L. M., Sucharew, H., Britto, M. T., \& Epstein, J. N. (2011). Physicians' shared decision-making behaviors in attention-deficit/hyperactivity disorder care. Archives of Pediatric and Adolescent Medicine, 165(11), 1013-1019. doi:10.1001/archpediatrics. 2011.154

Brown, J. D., \& Krupnik, J. (2010). Therapeutic alliance in pediatric primary care: Preliminary evidence for a relationship with physician communication style and mothers' satisfaction. Journal of Developmental and Behavioral Pediatrics, 31(2), 83-91. doi:10.1097/ DBP.0b013e3181cda770
Brown, J. D., \& Wissow, L. S. (2008). Discussion of maternal stress during pediatric primary care visits. Ambulatory Pediatrics, 8(6), 368-374. doi:10.1016/j.ambp.2008.08.004

Buckley, A., \& Savage, E. (2010). Preoperative information needs of children undergoing tonsillectomy. Journal of Clinical Nursing, 19, 2879-2887. doi:10.1111/j.1365-2702.2010.03273.x

Cahill, P., \& Papageorgiou, A. (2007a). Video analysis of communication in paediatric consultations in primary care. British Journal of General Practice, 57, 866-871. doi:10.3399/096016407782317838

Cahill, P., \& Papageorgiou, A. (2007b). Triadic communication in the primary care paediatric consultation: A review of the literature. British Journal of General Practice, 57, 904-911. doi:10.3399/096016407782317892

Caprara, A., \& Rodrigues, J. (2004). A relação assimétrica médico-paciente: Repensando o vínculo terapêutico. Ciência e Saúde Coletiva, 9(1), 139146. doi:10.1590/S1413-81232004000100014

Christakis, D. A., Johnston, B. D., \& Connell, F. A. (2001). Methodologic issues in pediatric outcomes research. Ambulatory Pediatrics, 1(1), 5962. doi:10.1367/1539-4409(2001)001<0059:MI IPOR $>2.0 . \mathrm{CO} ; 2$

Clark, N. M., Gong, M., Schork, M. A., Kaciroti, N., Evans, D., Roloff, D., ...Mellins, R. B. (2000). Long-term effects of asthma education for physicians on patient satisfaction and use of health services. European Respiratory Journal, 16(1), 15-21. doi:10.1034/j.1399-3003.2000.16a04.x

Clarke, J. N., \& Fletcher, P. (2003). Communication issues faced by parents who have a child diagnosed with cancer. Journal of Pediatric Oncology Nursing, 20(4), 175-191. doi:10.1177/1043454203254040

Cohen, S. Y., \& Wamboldt, F. S. (2000). The parentphysician relationship in pediatric asthma care. Journal of Pediatric Psychology, 25(2), 69-77. doi:10.1093/jpepsy/25.2.69

Coleman, W. (2002). Family-focused pediatrics: A primary care family systems approach to psychosocial problems. Current Problems in Pediatric and Adolescent Health Care, 32(8), 260-305. doi:10.1067/mps.2002.125468

Conboy, L. A., Macklin, E., Kelley, J., Kokkotou, E., Lembo, A., \& Kaptchuk, T. (2010). Which patients improve: Characteristics increasing sen- 
sitivity to a supportive patient-practitioner relationship. Social Science and Medicine, 70(3), 479-484. doi:10.1016/j.socscimed.2009.10.024

Cousino, M., Hazen, R., Yamokoski, A., Miller, V., Zyzanski, S., Drotar, D., \& Kodisk, E. (2011). Parent participation and physician-parent communication during informed consent in child leukemia. Pediatrics, 128, 1544-1551. doi:10.1542/ peds.2010-3542

Coyne, I. (2008). Children's participation in consultations and decision-making at health service level: A review of the literature. International Journal of Nursing Studies, 45, 1682-1689. doi:10.1016/j.ijnurstu.2008.05.002

Coyne, I., \& Gallagher, P. (2011). Participation in communication and decision-making: Children and young people's experiences in a hospital setting. Journal of Clinical Nursing, 20, 2334 2343. doi:10.1111/j.1365-2702.2010.03582.x

Coyne, I., \& Harder, M. (2011). Children's participation in decision-making: Balancing protection with shared decision-making using a situational perspective. Journal of Child Health Care, 15(4), 312-319. doi:10.1177/1367493511406570

Croom, A., Wiebe, D. J., Berg, C. A., Lindsay, R., Donaldson, D., Foster, C., ...Swinyard, M. T. (2011). Adolescent and parent perceptions of patient-centered communication while managing type 1 diabetes. Journal of Pediatric Psychology, 36(2), 206-215. doi:10.1093/jpepsy/jsq072

Crossley, J., \& Davies, H. (2005). Doctor's consultation with children and their parents: A model of competencies, outcomes and confounding influences. Medical Education, 39(8), 807-819. doi:10.1111/j.1365-2929.2005.02231.x

Crossley, J., Eiser, C., \& Davies, H. A. (2005). Children and their parents assessing the doctor-patient interaction: A rating system for doctors' communication skills. Medical Education, 39(8), 820828. doi:10.1111/j.1365-2929.2005.02230.x

Cruz-Hernández, M. (2004). Un renovado reto en la formación pediátrica: la relación médicopaciente-familia. Educación Médica, 7(4), 119 124. doi:10.4321/S1575-18132004000600008

Darby, C. (2002). Patient/parent assessment of the quality of care. Ambulatory Pediatrics, 2(4), 345-348. doi:10.1367/1539$-4409(2002) 002<0345:$ PPAOTQ $>2.0 . C O ; 2$

Deslandes, S. F. (2004). Análise do discurso oficial sobre a humanização da assistência hos- pitalar. Ciência \& Saúde Coletiva, 9(1), 7-14. doi:10.1590/S1413-81232004000100002

DiMatteo, M. R. (2003). Future directions in research on consumer-provider communication and adherence to cancer prevention and treatment. Patient Education and Counseling, 50(1), 2326. doi:10.1016/S0738-3991(03)00075-2

DiMatteo, M. R. (2004). The role of effective communication with children and their families in fostering adherence to pediatric regimens. $\mathrm{Pa}$ tient Education and Counseling, 55(3), 339-344. doi:10.1016/j.pec.2003.04.003

Drotar, D. (2009). Physician behavior in the care of pediatric chronic illness: Association with health outcomes and treatment adherence. Journal of Developmental \& Behavioral Pediatrics, 30(3), 246-254. doi:10.1097/DBP.0b013e3181a7ed42

Dubé, C. E., LaMonica, A., Boyle, W., Fuller, B., \& Burkholder, G. J. (2003). Self-assessment of communication skills preparedness: Adult versus pediatric skills. Ambulatory Pediatrics, 3(3), 137-141. doi:10.1367/15394409(2003)003<0137:SOCSPA $>2.0$

El Malla, H., Kreicbergs, U., Steineck, G., Wilderäng, U., Elborai, Y. E., \& Ylitalo, N. (2013). Parental trust in health care: A prospective study from children's cancer hospital in Egypt. PsychoOncology, 22(3), 548-554. doi:10.1002/ pon. 3028

Engelen, V., Haverman, L., Koopman, H., Schoutenvan Meeteren, N., Meijer-van der Bergh, E., Vrijmoet-Wiersma, J., ...Grootenhuis, M. (2010). Development and implementation of a patient reported outcome intervention (QLIC$\mathrm{ON}$ profile) in clinical paediatric oncology practice. Patient Education and Counseling, 81, 235-244. doi:10.1016/j.pec.2010.02.003

Farrell, M., Ryan, S., \& Langrick, B. (2001). "Breaking bad news" within a paediatric setting: An evaluation report of a collaborative education workshop to support health professionals. Journal of Advanced Nursing, 36(6), 765-775. doi:10.1046/j.1365-2648.2001.02042.x

Felt, B. T., \& O'Connor, M. E. (2003). Use of the child development review increases residents' discussion of behavioral problems. Ambulatory Pediatrics, 3(1), 2-8. doi:10.1367/1539$-4409(2003) 003<0002:$ UOTCDR $>2.0$

Fiks, A. G., Localio, A. R., Alessandrini, E. A., Asch, D. A., \& Guevara, J. P. (2010). Shared decicion- 
making in pediatrics: A national perspective. Pediatrics, 126(2), 306-314. doi:10.1542/ peds.2010-0526

Fisher, M. J., \& Broome, M. E. (2011). Parentprovider communication during hospitalization. Journal of Pediatric Nursing, 26, 58-69. doi:10.1016/j.pedn.2009.12.071

Gabarra, L. M., \& Crepaldi, M. A. (2011). A comunicação médico-paciente pediátrico-família na perspectiva da criança. Psicologia Argumento, 29(65), 209-218.

Gabe, J., Olumide, G., \& Bury, M. (2004). 'It takes three to tango': A framework for understanding patient partnership in paediatric clinics. Social Science and Medicine, 59(5), 1071-1079. doi:10.1016/j.socscimed.2003.09.035

Galil, A., Bachner, Y. G., Merrick, J., Flusser, H., Lubetzky, H., Heiman, N., \& Carmel, S. (2006). Physician-parent communication as predictor of parent satisfaction with child development services. Research in Developmental Disabilities, 27, 233-242. doi:10.1016/j.ridd.2005.03.004

Garrafa, V., \& Albuquerque, M. C. (2001). Enfoque bioético de la comunicación en la relación médico-paciente en las unidades de terapia intensiva pediátricas. Acta Bioethica, 7(2), 355-367. doi:10.4067/S1726-569X2001000200014

Goore, Z., Mangione-Smith, R., Elliott, M. N., McDonald, L., \& Kravitz, R. L. (2001). How much explanation is enough? A study of parent requests for information and physician responses. Ambulatory Pediatrics, 1(6), 326-332. doi:10.1367/1539-4409(2001)001<0326:HMEI $\mathrm{EA}>2.0 . \mathrm{CO} ; 2$

Gordon, B. K., Jaaniste, T., Bartlett, K., Perrin, M., Jackson, A., Sandstrom, A., ...Seehan, S. (2010). Child and parental surveys about prehospitalization information provision. Child: Care, Health and Development, 37(5), 727-733. doi:10.1111/j.1365-2214.2010.01190.x

Gough, J. K., Frydenberg, A. R., Donath, S. K., \& Marks, M. M. (2009). Simulated parents: Developing paediatric trainees' skills in giving bad news. Journal of Paediatrics and Child Health, 45(3), 133-138. doi:10.1111/j.14401754.2009.01440.x

Hallström, I. (2004). Parents' and children's involvement in decision-making during hospitalization. Nursing Times Research, 9(4), 263-269. doi:10.1046/j.1365-2702.2003.00877.x
Hammond, M., \& McLean, E. (2009). What parents and carers think medical students should be learning about communication with children and families. Patient Education and Counseling, 76(3), 368-375. doi:10.1016/j.pec.2009.07.020

Harrington, N. G., Norling, G. R., Witte, F. M., Taylor, J., \& Andrews, J. E. (2007). The effects of communication skills training on pediatricians' and parents' communication during "sick child" visits. Health Communication, 21(2), 105-114. doi:10.1080/10410230701306974

Hart, C. N., Drotar, D., Gori, A., \& Lewin, L. (2006). Enhancing parent-provider communication in ambulatory pediatric practice. Patient Education and Counseling, 63(1-2), 38-46. doi:10.1016/j. pec.2005.08.007

Hart, C. N., Kelleher, K. J., Drotar, D., \& Scholle, S. H. (2007). Parent-provider communication and parental satisfaction with care of children with psychosocial problems. Patient Education and Counseling, 68(2), 179-185. doi:10.1016/j. pec.2007.06.003

Hayutin, L. G., Reed-Knight, B., Blount, R. L., Lewis, J., \& McCormick, M. L. (2009). Increasing parent-pediatrician communication about children's psychosocial problems. Journal of Pediatric Psychology, 34(10), 1155-1164. doi:10.1093/jpepsy/jsp012

Heneghan, A. M., Mercer, M., \& DeLeone, N. L. (2004). Will mothers discuss parenting stress and depressive symptoms with their child's pediatrician? Pediatrics, 113(3), 460-467.

Howells, R. J., Davies, H. A., \& Silverman, J. D. (2006). Teaching and learning consultation skills for paediatric practice. Archives of Disease in Childhood, 91, 367-370. doi:10.1136/ adc. 2005.073775

Howells, R. J., Davies, H. A., Silverman, J. D., Archer, J. C., \& Mellon, A. F. (2010). Assessment of doctors' consultation skills in the paediatric setting: The Paediatric Consultation Assessment Tool. Archives of Disease in Childhood, 95, 323-329. doi:10.1136/adc.2008.146191

Howells, R., \& Lopez, T. (2008). Better communication with children and parents. Paediatrics and Child Health, 18(8), 381-385. doi:10.1016/j. paed.2008.05.007

Jirasevijinda, T., \& Brown, L. C. (2010). Jeopardy!: An innovative approach to teach psychosocial aspects of pediatrics. Patient Education and Counseling, 80, 333-336. doi:10.1016/j. pec.2010.06.002 
Kain, Z. N., Maclaren, J. E., Hammell, C., Novoa, C., Fortier, M. A., Huszti, H., \& Mayes, L. (2009). Healthcare provider-child-parent communication in the preoperative surgical setting. Pediatric Anesthesia, 19, 376-384. doi:10.1111/j.14609592.2008.02921.x

Kästel, A., Enskär, K., \& Björk, O. (2011). Parents' views on information in childhood cancer care. European Journal of Oncology Nursing, 15, 290-295. doi:10.1016/j.ejon.2010.10.007

Kemper, K. J., Foy, J. M., Wissow, L., \& Shore, S. (2008). Enhancing communication skills for pediatric visits through on-line training using video demonstrations. BMC Medical Education, 8(8), 1-9. doi:10.1186/1472-6920-8-8

Kiguli, S., Mafigiri, D., Nakigudde, J., Dalen, J., \& Vleuten, C. (2011). A qualitative study of caregivers' expectations and communication desires during medical consultation for sick children in Uganda. Patient Education and Counseling, 84, 217-222. doi:10.1016/j.pec.2010.07.015

Knighting, K., Rowa-Dewar, N., Malcolm, C., Kearney, N., \& Gibson, F. (2010). Children's understanding of cancer and health behaviors. Child: Care, Health and Development, 289-299. doi:10.1111/j.1365-2214.2010.01138.x

Koopman, H. M., Baars, R. M., Chaplin, J., \& Zwinderman, K. H. (2004). Illness through the eyes of the child: The development of children's understanding of the causes of illness. Patient Education and Counseling, 55, 363-370.

Korsch, B. M., Gozzi, E. K., \& Francis, V. (1968). Gaps in doctor-patient communication: I. Doctor-patient interaction and patient satisfaction. Pediatrics, 42(5), 855-871.

Kreps, G. L., Bonaguro, E. W., \& Query, J. L. (1998). The history and development of the field of health communication. In L. D. Jackson \& B. K. Duffy (Eds.), Health communication research: Guide to developments and directions (pp. 1-15). Westport, CT: Greenwood Press.

Lambert, V., Glacken, M., \& McCarron, M. (2011). Communication between children and health professionals in a child hospital setting: A Child Transitional Communication Model. Journal of Advanced Nursing, 67(3), 569-582. doi:10.1111/ j.1365-2648.2010.05511.x

Liu, G. C., Harris, M. A., Keyton, S. A., \& Frankel, R. M. (2007). Use of unstructured parent narratives to evaluate medical student competencies in communication and professionalism. $\mathrm{Ambu}$ - latory Pediatrics, 7(3), 207-213. doi:10.1016/j. ambp.2007.03.001

Mack, J. W., Wolfe, J., Grier, H. E., Cleary, P. D., \& Weeks, J. C. (2006). Communication about prognosis between parents and physicians of children with cancer: Parent preferences and the impact of prognostic information. Journal of Clinical Oncology, 24(33), 5265-5270. doi:10.1200/JCO.2006.06.5326

Mangione-Smith, R., McGlynn, E. A., Elliott, M. N., McDonald, L., Franz, C. E., \& Kravitz, R. L. (2001). Parent expectations for antibiotics, physician-parent communication, and satisfaction. Archives of Pediatric and Adolescent Medicine, 155, 800-806.

Märtenson, E. K., \& Fägerskiöld, A. M. (2007). A review of children's decision-making competence in health care. Journal of Clinical Nursing, 17(23), 3131-3141. doi:10.1111/j.13652702.2006.01920.x

Märtenson, E. K., Fägerskiöld, A. M., \& Berteró, C. M. (2007). Information exchange in paediatric settings: An observational study. Paediatric Nursing, 19(7), 40-43.

McGraw, M., Fellows, S., Long, A., Millar, H., Muir, G., Thomson, A., ...Williams, S. (2012). Feedback on doctors' performance from parents and carers of children: A national pilot study. Archives of Disease in Childhood, 97, 206-210. doi:10.1136/adc.2010.203174

Mendonça, M. B. (2007). Análise do processo de comunicação entre médico, acompanhante e paciente em onco-hematologia pediátrica (Dissertação de mestrado, Universidade de Brasília, DF, Brasil).

Miller, V. A., Drotar, D., Burant, C., \& Kodish, E. (2005). Clinician-parent communication during informed consent for pediatric leukemia trials. Journal of Pediatric Psychology, 30(3), 219229. doi:10.1093/jpepsy/jsi032

Moseley, K. L., Clark, S. J., Gebremariam, A., Sternthal, M. J., \& Kemper, A. R. (2006). Parent's trust in their child's physician: Using an Adapted Trust in Physician Scale. Ambulatory Pediatrics, 6(1), 58-61. doi:10.1016/j.ambp.2005.08.001

Nestel, D., Taylor, S., \& Spender, Q. (2004). Evaluation of an inter-professional workshop to develop a psychosocial assessment and child-centred communication training programme for paediatricians in training. BMC Medical Education, 4(25), 1-10. doi:10.1186/1472-6920-4-25 
Nikendei, C., Bosse, H. M., Hoffmann, K., Möltner, K., Hancke, R., Conrad, C., ...Schultz, J. H. (2011). Outcome of parent-physician communication skills training for pediatric residents. Patient Education and Counseling, 82, 94-99. doi:10.1016/j.pec.2009.12.013

Nobile, C., \& Drotar, D. (2003). Research on the quality of parent-provider communication in pediatric care: Implications and recommendations. Developmental and Behavioral Pediatrics, 24(4), 279-290.

Nova, C., Vegni, E., \& Moja, E. A. (2005). The physician-patient-parent communication: A qualitative perspective on the child's contribution. $\mathrm{Pa}$ tient Education and Counseling, 58(3), 327-333. doi:10.1016/j.pec.2005.02.007

O'Keefe, M. (2001). Should parents assess the interpersonal skills of doctors who treat their children? A literature review. Journal of Paediatric Child Health, 37, 531-538. 10.1046/j.14401754.2001.00755.x

Oliveira, V. Z., \& Gomes, W. B. (2004). Comunicação médico-paciente e adesão ao tratamento em adolescentes portadores de doenças orgânicas crônicas. Estudos de Psicologia (Natal), 9(3), 459469. doi:10.1590/S1413-294X2004000300008

Ong, L. M. L., Haes, J. C. J. M., Hoos, A. M., \& Lammes, F. B. (1995). Doctor-patient communication: A review of literature. Social Science and Medicine, 40(7), 903-918.

Outsubo, A. P. N., \& Becker, E. (2005). Crianças com doenças crônicas falam sobre doença: Uma pesquisa exploratória. Cadernos de Pós-Graduação em Distúrbios do Desenvolvimento, 5(1), 39-46.

Patistea, E., \& Babatsikou, F. (2003). Parent's perceptions of the information provided to them about their child's leukemia. European Journal of Oncology Nursing, 7(3), 172-181.

Périco, G. V., Grosseman, S., Robles, A. C. C., \& Stoll, C. (2006). Percepção de mães sobre a assistência prestada a seus filhos por estudantes de medicina da sétima fase: Estudo de caso no ambulatório de pediatria de um hospital universitário. Revista Brasileira de Educação Médica, 30(2), 49-55. doi:10.1590/S0100-55022006000200007

Perosa, G. B., \& Gabarra, L. M. (2004). Explicações de crianças internadas sobre a causa das doenças: Implicações para a comunicação profissional de saúde-paciente. Interface - Comunicação, Saúde, Educação, 8(14), 135-147. doi:10.1590/ S1414-32832004000100008
Perosa, G. B., \& Ranzani, P. M. (2008). Capacitação do médico para comunicar más notícias à criança. Revista Brasileira de Educação Médica, 32(4), 468-473. doi:10.1590/S010055022008000400009

Pinto, L. M. O. (2010). Comunicação pediatra, paciente e acompanhante: uma análise comparativa entre níveis assistenciais (Dissertação de mestrado, Universidade de Brasília, DF, Brasil).

Ranzani, P. M. (2009). O processo de comunicação médico/familiar/criança: A percepção de mães de crianças portadoras de doenças crônicas graves (Dissertação de mestrado, Universidade Estadual Paulista Júlio de Mesquita Filho, Botucatu, SP, Brasil).

Rider, E. A., Volkan, K., \& Hafler, J. P. (2008). Pediatric resident's perceptions of communication competencies: Implications for teaching. Medical Teaching, 30(7), 208-217. doi:10.1080/01421590802208842

Ringnér, A., Jansson, L., \& Graneheim, U. H. (2010). Professional caregivers' perceptions of providing information to parents of children with cancer. Journal of Pediatric Oncology Nursing, 20(10), 1-9. doi:10.1177/1043454210377175

Rotenberg, K. J., Cunningham, J., Hayton, N., Hutson, L., Jones, L., Marks, C., ...Betts, L. R. (2008). Development of a children's trust in general physicians scale. Child: Care, Health and Development, 34(6), 748-756. doi:10.1111/ j.1365-2214.2008.00872.x

Schuster, M. A., Duan, N., Regalado, M., \& Klein, D. J. (2000). Anticipatory guidance: What information do parents receive? What information do they want? Archives of Pediatric and Adolescent Medicine, 154(12), 1191-1198. doi:10.1001/ archpedi.154.12.1191

Scrimin, S., Axia, G., Tremolada, M., Pillon, M., Capello, F., \& Zanesco, L. (2005). Conversational strategies with parents of newly diagnosed leukaemic children: An analysis of 4880 conversational turns. Support Care Cancer, 13(5), 287294. doi:10.1007/s00520-004-0679-1

Sharma, A., Prematta, T., \& Fausnight, T. (2012). A pediatric food allergy support group can improve parent and physician communication: Results of a parent survey. Journal of Allergy, 2012, 1-3. doi:10.1155/2012/168053

Silva, M. M. (2000). Consulta pediátrica: efeito de procedimentos instrucionais sobre os temas tratados (Tese de doutorado, Universidade de Brasília, DF, Brasil). 
Sleath, B., Ayala, G. X., Washington, D., Davis, S., Williams, D., Tudor, G., ...Gillette, C. (2011). Caregiver rating of provider participatory decision-making style and caregiver and child satisfaction with pediatric asthma visits. $\mathrm{Pa}$ tient Education and Counseling, 85, 286-289. doi:10.1016/j.pec.2010.09.016

Sleath, B., Carpenter, D. M., Slota, C., Williams, D., Tudor, G., Yeatts, K., ...Ayala, G. X. (2012). Communication during pediatric asthma visits and self-reported asthma medication adherence. Pediatrics, 130(4), 1-7. doi:10.1542/peds.20120913

Sobo, E. J. (2004). Good communication in pediatric cancer care: A culturally-informed research agenda. Journal of Pediatric Oncology Nursing, 21(3), 150-154. doi:10.1177/1043454204264408

Stivers, T. (2001). Negotiating who presents the problem: Next speaker selection in pediatric encounters. Journal of Communication, 51(2), 252-282. doi:10.1111/j.1460-2466.2001

Stivers, T. (2012). Physician-child interaction: When children answer physicians' questions in routine medical encounters. Patient Education and Counseling, 87, 3-9. doi:10.1016/j. pec. 2011.07 .007

Stivers, T., \& Majid, A. (2007). Questioning children: Interactional evidence of implicit bias in medical interviews. Social Psychology Quaterly, 70(4), 424-441.

Swedlund, M. P., Schumacher, J. B., Young, H. N., \& Cox, E. D. (2012). Effect of communication style and physician-family relationships on satisfaction with pediatric chronic disease care. Health Communication, 27(5), 498-505. doi:10 $.1080 / 10410236.2011 .616632$

Tates, K., \& Meeuwesen, L. (2000). "Let mum have her say": Turntaking in doctor-parent-child communication. Patient Education and Counseling, 40(2), 151-162. doi:10.1016/S07383991(99)00075-0

Tates, K., \& Meeuwesen, L. (2001). Doctor-parentchild communication: A (re)view of the literature. Social Science and Medicine, 52(6), 839851. doi:10.1016/S0277-9536(00)00193-3

Tates, K., Elbers, E., Meeuwesen, L., \& Bensing, J. (2002). Doctor-parent-child relationships: A 'pas de trois'. Patient Education and Counseling, 48(1), 5-14. doi:10.1016/S07383991(02)00093-9
Tates, K., Meeuwesen, L., Bensing, J., \& Elbers, E. (2002). Joking or decision-making? Affective and instrumental behaviour in doctor-parent-child communication. Psychology and Health, 17(3), 281-295. doi:10.1080/08870440290029548

Tates, K., Meeuwesen, L., Elbers, E., \& Bensing, J. (2002). "I've come for his throat": Roles and identities in doctor-parent-child communication. Child: Care, Health \& Development, 28(1), 109116. doi:10.1046/j.1365-2214.2002.00248.x

Taylor, S., Haase-Casanovas, S., Weaver, T., Kidd, J., \& Garralda, E. M. (2010). Child involvement in the paediatric consultation: A qualitative study of children and carers' views. Child: Care, Health and Development, 36(5), 678-685. doi:10.1111/j.1365-2214.2010.01076.x

Vaknin, O., \& Zisk-Rony, R. Y. (2010). Including children in medical decisions and treatments: Perceptions and practices of healthcare providers. Child: Care, Health and Development, 37(4), 533-539. doi:10.1111/j.13652214.2010.01153.x

Van Dulmen, S. (2004). Pediatrician-parent-child communication: Problem-related or not? $\mathrm{Pa}$ tient Education and Counseling, 52(1), 61-68. doi:10.1016/S0738-3991(02)00250-1

Van Dulmen, S., \& Holl, R. A. (2000). Effects of continuing paediatric education in interpersonal communication skills. European Journal of Pediatrics, 159(7), 489-495. doi:10.1007/ s004310051316

Varni, J. W., Quiggins, D. J. L., \& Ayala, G. X. (2000). Development of the pediatric hematology/oncology parent satisfaction survey. Children's Health Care, 29(4), 243-255. doi:10.1207/ S15326888CHC2904_2

Vatne, T. M., Finset, A., Ornes, K., \& Ruland, C. M. (2010). Application of the Verona Coding Definitions of Emotional Sequences (VR-CoDES) on a pediatric data set. Patient Education and Counseling, 80, 399-404. doi:10.1016/j. pec.2010.06.026

Vatne, T. M., Slaughter, L., \& Ruland, C. M. (2010). How children with cancer communicate and think about symptoms. Journal of Pediatric Oncology Nursing, 27(1), 24-32. doi:10.1177/1043454209349358

Viegas, D. (2003). A importância do diálogo na consulta pediátrica. Revista Brasileira de Medicina, 9(1), 20-22. 
Washington, D., Yeatts, K., Sleath, B., Ayala, G. X., Gillette, C., Williams, D., ...Tudor, G. (2012). Communication and education about triggers and environmental control strategies during pediatric asthma visits. Patient Education and Counseling, 86, 63-69. doi:10.1016/j. pec.2011.04.015

Wassmer, E., Minnaar, G., Aal, N. A., Atkinson, M., Gupta, E., Yuen, S., \& Rylance, G. (2004). How do paediatricians communicate with children and parents? Acta Paediatrica, 93(11), 15011506. doi:10.1080/08035250410015079

Wildman, B. G., Stancin, T., Golden, C., \& Yerkey, T. (2004). Maternal distress, child behaviour, and disclosure of psychosocial concerns to a paediatrician. Child, Care, Health \& Development, 30(4), 385-394. doi:10.1111/j.13652214.2004.00428.x

Wissow, L. S., Brown, J. D., \& Krupnick, J. (2010). Therapeutic alliance in pediatric primary care: Preliminary evidence for a relationship with physician communication style and mother's satisfaction. Journal of Developmental \& Behavioral Pediatrics, 31(2), 83-91. doi:10.1097/ DBP.0b013e3181cda770

Wissow, L. S., Gadomski, A., Roter, D., Larson, S., Brown, J., Zachary, C., ...Wang, M. (2008). Improving child and parent mental health in primary care: A cluster-randomized trial of communication skills training. Pediatrics, 121(2), 266-275. doi:10.1542/peds.2007-0418

Wissow, L., Gadomski, A., Roter, D., Larson, S., Lewis, B., \& Brown, J. (2012). Aspects of mental health communication skills training that predict parent and child outcomes in pediatric primary care. Patient Education and Counseling, 82(2), 226-232. doi:10.1016/j.pec.2010.03.019

Wissow, L. S., \& Kimel, M. B. (2002). Assessing provider-patient-parent communication in the pediatric emergency department. Ambulatory Pediatrics, 2(4), 323-329. doi:10.1367/15394409(2002)002<0323:APPPCI $>2.0$

Wissow, L. S., Larson, S., Anderson, J., \& Hadjiisky, E. (2005). Pediatric residents' responses that discourage discussion of psychosocial problems in primary care. Pediatrics, 115(6), 1569-1578. doi:10.1542/peds.2004-1535

Young, B., Dixon-Woods, M., Windridge, K. C., \& Heney, D. (2003). Managing communiction with young people who have a potentially life threatening chronic illness: Qualitative study of patients and parents. British Medical Journal, 326(7384), 305-309.

Young, B., Ward, J., Forsey, M., Gravenhorst, K., \& Salmon, P. (2011a). Examining the validity of the unitary theory of clinical relationships: Comparison of observed and experienced parent-doctor interaction. Patient Education and Counseling, 85, 60-67. doi:10.1016/j.pec.2010.08.027

Young, B., Ward, J., Salmon, P., Gravenhorst, K., Hill, J., \& Eden, T. (2010). Parents' accounts of the presence of their preadolescent child during discussions with doctors in the months after the child's diagnosis with serious illness: Qualitative interview study. Archives of Disease in Childhood, 95(1), 1230-1238.

Young, B., Ward, J., Salmon, P., Gravenhorst, K., Hill, J., \& Eden, T. (2011b). Parents' experiences of their children's presence in discussions with physicians about leukemia. Pediatrics, 127(5), 1230-1238. doi:10.1542/peds.2010-2402

Young, S., \& Oppenheimer, D. M. (2009). Effect of communication strategy on personal risk perception and treatment adherence intentions. Psychology, Health and Medicine, 14(4), 430442. doi:10.1080/13548500902890103

Zolnierek, K. B. H., \& DiMatteo, M. R. (2009). Physician communication and patient adherence and treatment: A meta-analysis. Medical Care, 47(8), 826-834. doi:10.1097/MLR.0b013e31819a5acc

Zwaanswijk, M., Tates, K., van Dulmen, S., Hoogerbrugge, P. M., Kamps, W. A., \& Bensing, J. M. (2007). Young patients', parents', and survivors' communication preferences in paediatric oncology: Results of online focus groups. $B M C$ Pediatrics, 7(35), 1-10. doi:10.1186/1471-24317-35

Zwaanswijk, M., Tates, K., van Dulmen, S., Hoogerbrugge, P. M., Kamps, W. A., Beishuizen, A., \& Bensing, J. M. (2011). Communicating with child patients in pediatric oncology consultations: A vignette study on child patients', parents', and survivors' communication preferences. Psycho-Oncology, 20, 269-277. doi:10.1002/pon.1721 


\section{Anexo A - Tabela 1: Artigos com Delineamento Descritivo}

\begin{tabular}{|c|c|c|c|c|c|}
\hline Autores e Ano & Objetivos & $\begin{array}{l}\text { Instrumentos } \\
\text { e Técnicas }\end{array}$ & Participantes & Análise & Principais Resultados \\
\hline $\begin{array}{l}\text { Armelin et al. } \\
\qquad(2005)\end{array}$ & $\begin{array}{l}\text { Descrever a } \\
\text { comunicação }\end{array}$ & $\begin{array}{l}\text { Entrevistas } \\
\text { Observação }\end{array}$ & $\begin{array}{c}2 \text { crianças } \\
\text { (12 e } 14 \text { anos }) \\
13 \text { pediatras }\end{array}$ & Qualitativa & $\begin{array}{l}\text { A comunicação ocorre entre } \\
\text { médico e cuidador }\end{array}$ \\
\hline $\begin{array}{c}\text { Blumberg \& } \\
\text { O'Conor (2004) }\end{array}$ & $\begin{array}{l}\text { Avaliar relação } \\
\text { entre humor dos } \\
\text { pais e instruções }\end{array}$ & $\begin{array}{l}\text { Entrevistas } \\
\text { Mental Health } \\
\text { Inventory }\end{array}$ & $\begin{array}{c}2068 \text { cuidadores } \\
\text { de crianças }(4-35 \\
\text { meses })\end{array}$ & Quantitativa & $\begin{array}{l}\text { Pais com humor positivo } \\
\text { indicaram mais discussão de } \\
\text { ações preventivas }\end{array}$ \\
\hline $\begin{array}{l}\text { Brinkman et al. } \\
\text { (2011) }\end{array}$ & $\begin{array}{c}\text { Avaliar } \\
\text { comunicação sobre } \\
\text { decisões }\end{array}$ & $\begin{array}{l}\text { Videogravação } \\
\text { e Observing } \\
\text { Patient } \\
\text { Involvement } \\
\text { Scale }\end{array}$ & $\begin{array}{l}10 \text { pediatras } \\
\text { e } 26 \text { famílias } \\
\text { (crianças } 6-10 \\
\text { anos) }\end{array}$ & Quantitativa & $\begin{array}{c}\text { Houve associação } \\
\text { entre interação e dados } \\
\text { socioeconômicos dos pais. }\end{array}$ \\
\hline $\begin{array}{c}\text { Brown \& } \\
\text { Wissow (2008) }\end{array}$ & $\begin{array}{l}\text { Analisar relação } \\
\text { entre estresse } \\
\text { discutido e } \\
\text { satisfação }\end{array}$ & $\begin{array}{l}\text { General Health } \\
\text { Questionnaire } \\
\text { Outros } \\
\text { questionários }\end{array}$ & $\begin{array}{l}747 \text { mães } \\
\text { (crianças 5-16 } \\
\text { anos) }\end{array}$ & Quantitativa & $\begin{array}{l}35 \% \text { das mães discutiram sobre } \\
\text { estresse na consulta e estas } \\
\text { indicaram maior satisfação }\end{array}$ \\
\hline $\begin{array}{c}\text { Buckley \& } \\
\text { Savage (2010) }\end{array}$ & $\begin{array}{l}\text { Avaliar preferência } \\
\text { de crianças por } \\
\text { informação }\end{array}$ & $\begin{array}{l}\text { Entrevistas } \\
\text { Análise de } \\
\text { desenhos }\end{array}$ & $\begin{array}{l}9 \text { crianças }(6-9 \\
\text { anos) }\end{array}$ & Qualitativa & $\begin{array}{l}\text { Crianças comunicam } \\
\text { diretamente preferências por } \\
\text { informação }\end{array}$ \\
\hline $\begin{array}{c}\text { Cahill \& } \\
\text { Papageorgiou } \\
(2007 \mathrm{a})\end{array}$ & $\begin{array}{l}\text { Analisar a } \\
\text { comunicação } \\
\text { triádica em } \\
\text { consultas }\end{array}$ & Videogravação & $\begin{array}{c}16 \text { médicos } \\
\text { (crianças 6-12 } \\
\text { anos) }\end{array}$ & Mista & $\begin{array}{c}\text { Pouca participação da } \\
\text { criança (em média } 5,42 \% \text { ) e } \\
\text { dependente da inserção por } \\
\text { cuidadores e médicos }\end{array}$ \\
\hline $\begin{array}{c}\text { Clarke \& } \\
\text { Fletcher (2003) }\end{array}$ & $\begin{array}{l}\text { Avaliar percepção } \\
\text { dos pais sobre } \\
\text { informações }\end{array}$ & Entrevistas & 29 pais & Qualitativa & $\begin{array}{c}\text { Pais destacam importância do } \\
\text { apoio do médico }\end{array}$ \\
\hline $\begin{array}{l}\text { Coyne \& } \\
\text { Gallagher } \\
(2011)\end{array}$ & $\begin{array}{l}\text { Analisar percepção } \\
\text { de crianças sobre } \\
\text { comunicação }\end{array}$ & $\begin{array}{l}\text { Entrevistas } \\
\text { Grupos Focais }\end{array}$ & $\begin{array}{c}55 \text { pacientes }(7- \\
18 \text { anos })\end{array}$ & Qualitativa & $\begin{array}{l}\text { Crianças querem participar } \\
\text { da interação, porém há } \\
\text { preferências individuais sobre } \\
\text { esta inclusão }\end{array}$ \\
\hline $\begin{array}{l}\text { Croom et al. } \\
\quad(2011)\end{array}$ & $\begin{array}{l}\text { Analisar associação } \\
\text { entre comunicação } \\
\text { e adesão }\end{array}$ & $\begin{array}{l}\text { Questionários } \\
\text { específicos } \\
\text { Exames clínicos }\end{array}$ & $\begin{array}{c}190 \text { díades } \\
\text { (pacientes entre } \\
10 \text { e } 14 \text { anos) }\end{array}$ & Quantitativa & $\begin{array}{l}\text { Qualidade da comunicação } \\
\text { foi associada a adesão aos } \\
\text { cuidados e melhor controle de } \\
\text { taxas metabólicas }\end{array}$ \\
\hline $\begin{array}{l}\text { Dubé et al. } \\
\text { (2003) }\end{array}$ & $\begin{array}{l}\text { Avaliar treinamento } \\
\text { durante graduação }\end{array}$ & $\begin{array}{l}\text { Questionário } \\
\text { específico }\end{array}$ & 143 residentes & Quantitativa & $\begin{array}{l}\text { Mais da metade não observou } \\
\text { consulta pediátrica e } 12 \% \text { não } \\
\text { recebeu treino específico }\end{array}$ \\
\hline $\begin{array}{l}\text { El Malla et al. } \\
\qquad(2013)\end{array}$ & $\begin{array}{l}\text { Avaliar } \\
\text { comunicação, } \\
\text { confiança e } \\
\text { satisfação }\end{array}$ & $\begin{array}{l}\text { Questionários } \\
\text { específicos }\end{array}$ & 304 pais & Quantitativa & $\begin{array}{l}\text { Comunicação satisfatória, } \\
\text { provisão de informações } \\
\text { e suporte são associadas à } \\
\text { confiança dos pais }\end{array}$ \\
\hline $\begin{array}{l}\text { Engelen et al. } \\
\qquad(2010)\end{array}$ & $\begin{array}{c}\text { Descrever } \\
\text { implementação de } \\
\text { protocolo }\end{array}$ & $\begin{array}{l}\text { Quality of Life } \\
\text { In Childhood } \\
\text { Oncology (QLIC- } \\
\text { ON) }\end{array}$ & - & Mista & $\begin{array}{l}\text { Protocolos educativos são } \\
\text { relevantes para melhorar o } \\
\text { atendimento pediátrico e a } \\
\text { comunicação }\end{array}$ \\
\hline $\begin{array}{l}\text { Farrell et al. } \\
\quad(2001)\end{array}$ & $\begin{array}{c}\text { Avaliar a } \\
\text { eficiência de } \\
\text { intervenção sobre a } \\
\text { comunicação }\end{array}$ & $\begin{array}{l}\text { Palestras e role } \\
\text { play } \\
\text { Questionários } \\
\text { específicos }\end{array}$ & 45 pediatras & Mista & $\begin{array}{l}\text { Todos os participantes } \\
\text { destacaram a eficiência do } \\
\text { treinamento. Destacou-se a } \\
\text { importância do feedback }\end{array}$ \\
\hline $\begin{array}{l}\text { Fiks et al. } \\
(2010)\end{array}$ & $\begin{array}{l}\text { Analisar padrões } \\
\text { de decisão } \\
\text { compartilhada }\end{array}$ & $\begin{array}{c}\text { Medical } \\
\text { Expenditure } \\
\text { Panel Survey }\end{array}$ & $\begin{array}{l}4135 \text { famílias } \\
\text { (crianças } 0-17 \\
\text { anos) }\end{array}$ & Quantitativa & $\begin{array}{l}\text { Decisões compartilhadas } \\
\text { promovem melhor saúde. }\end{array}$ \\
\hline
\end{tabular}




\begin{tabular}{|c|c|c|c|c|c|}
\hline Autores e Ano & Objetivos & $\begin{array}{l}\text { Instrumentos } \\
\text { e Técnicas }\end{array}$ & Participantes & Análise & Principais Resultados \\
\hline $\begin{array}{c}\text { Fisher \& } \\
\text { Broome (2011) }\end{array}$ & $\begin{array}{l}\text { Comparar } \\
\text { percepção sobre } \\
\text { comunicação }\end{array}$ & Entrevistas & $\begin{array}{l}\text { Dez pais, } \\
\text { enfermeiros e } \\
\text { médicos }\end{array}$ & Qualitativa & $\begin{array}{l}\text { Participantes destacaram } \\
\text { comunicação inclusiva e } \\
\text { comportamentos facilitadores }\end{array}$ \\
\hline $\begin{array}{c}\text { Gabarra \& } \\
\text { Crepaldi (2011) }\end{array}$ & $\begin{array}{c}\text { Avaliar a percepção } \\
\text { da criança }\end{array}$ & Entrevistas & $\begin{array}{c}15 \text { crianças }(5-13 \\
\text { anos) }\end{array}$ & Qualitativa & $\begin{array}{l}\text { Crianças compreendem sua } \\
\text { doença e tratamento, mas } \\
\text { referem exclusão. }\end{array}$ \\
\hline $\begin{array}{l}\text { Galil et al. } \\
\text { (2006) }\end{array}$ & $\begin{array}{l}\text { Avaliar relação } \\
\text { entre comunicação } \\
\text { e satisfação }\end{array}$ & $\begin{array}{l}\text { Questionários } \\
\text { específicos }\end{array}$ & $\begin{array}{l}90 \text { cuidadores } \\
\text { (crianças entre } 6 \\
\text { meses e } 6 \text { anos) }\end{array}$ & Quantitativa & $\begin{array}{c}\text { A comunicação é preditora } \\
\text { da satisfação de cuidadores, } \\
\text { com ênfase em decisões } \\
\text { compartilhadas }\end{array}$ \\
\hline $\begin{array}{c}\text { Garrafa \& } \\
\text { Albuquerque } \\
\quad(2001)\end{array}$ & $\begin{array}{c}\text { Analisar a } \\
\text { comunicação entre } \\
\text { pais e médicos }\end{array}$ & $\begin{array}{l}\text { Grupos Focais } \\
\text { Entrevistas }\end{array}$ & $\begin{array}{c}12 \text { pais } \\
12 \text { médicos }\end{array}$ & Mista & $\begin{array}{l}\text { Comunicação insatisfatória. } \\
\text { Questões sobre serviço de } \\
\text { saúde são moderadoras da } \\
\text { comunicação }\end{array}$ \\
\hline $\begin{array}{l}\text { Goore et al. } \\
\quad(2001)\end{array}$ & $\begin{array}{l}\text { Avaliar relação } \\
\text { entre comunicação } \\
\text { e satisfação }\end{array}$ & $\begin{array}{l}\text { Taxonomy of } \\
\text { Requests by } \\
\quad \text { Patients }\end{array}$ & $\begin{array}{l}\text { Dez médicos } \\
\text { e } 306 \text { díades } \\
\text { (crianças } 2-10 \\
\text { anos) }\end{array}$ & Quantitativa & $\begin{array}{l}\text { Comunicação é importante } \\
\text { para pais, que indicaram } \\
\text { respostas com duração } \\
\text { moderada mais satisfatórias }\end{array}$ \\
\hline $\begin{array}{l}\text { Gordon et al. } \\
\qquad(2010)\end{array}$ & $\begin{array}{l}\text { Avaliar preferências } \\
\text { de crianças por } \\
\text { informação }\end{array}$ & $\begin{array}{l}\text { Questionários } \\
\text { específicos }\end{array}$ & $\begin{array}{l}102 \text { crianças } \\
(6-10 \text { anos })\end{array}$ & Quantitativa & $\begin{array}{c}\text { Crianças mais satisfeitas } \\
\text { manejam melhor questões } \\
\text { emocionais }\end{array}$ \\
\hline $\begin{array}{l}\text { Gough et al. } \\
\text { (2009) }\end{array}$ & $\begin{array}{l}\text { Descrever } \\
\text { experiência de } \\
\text { residentes }\end{array}$ & $\begin{array}{c}\text { Entrevistas } \\
\text { Videogravação }\end{array}$ & Nove residentes & $\begin{array}{l}\text { Análise } \\
\text { mista }\end{array}$ & $\begin{array}{l}\text { Destaque à segurança e } \\
\text { comportamentos facilitadores }\end{array}$ \\
\hline $\begin{array}{l}\text { Hallström } \\
\text { (2004) }\end{array}$ & $\begin{array}{c}\text { Analisar } \\
\text { participação de pais } \\
\text { e crianças }\end{array}$ & $\begin{array}{l}\text { Observação } \\
\text { direta }\end{array}$ & $\begin{array}{c}24 \text { díades } \\
\text { (crianças } 5 \\
\text { meses-18 anos) }\end{array}$ & Quantitativa & $\begin{array}{c}\text { Pediatras administram } \\
\text { comunicação e demandas não } \\
\text { são contempladas }\end{array}$ \\
\hline $\begin{array}{c}\text { Hammond \& } \\
\text { McLean (2009) }\end{array}$ & $\begin{array}{l}\text { Analisar percepção } \\
\text { de pais sobre } \\
\text { comunicação }\end{array}$ & $\begin{array}{l}\text { Grupos Focais } \\
\text { Questionários }\end{array}$ & 32 cuidadores & Mista & $\begin{array}{c}\text { Pais enfatizam necessidade de } \\
\text { humanização }\end{array}$ \\
\hline $\begin{array}{l}\text { Hart et al. } \\
\text { (2007) }\end{array}$ & $\begin{array}{l}\text { Avaliar a relação } \\
\text { comunicação/ } \\
\text { satisfação }\end{array}$ & $\begin{array}{l}\text { Questionários } \\
\text { específicos }\end{array}$ & $\begin{array}{l}804 \text { famílias } \\
\text { (crianças } 4-15 \\
\text { anos) }\end{array}$ & Quantitativa & $\begin{array}{c}\text { Pais indicaram boa } \\
\text { comunicação e } 82 \% \text { relataram } \\
\text { satisfação }\end{array}$ \\
\hline $\begin{array}{l}\text { Heneghan et al. } \\
\text { (2004) }\end{array}$ & $\begin{array}{c}\text { Avaliar } \\
\text { comunicação de } \\
\text { temas psicossociais }\end{array}$ & Grupos focais & $\begin{array}{l}44 \text { mães } \\
\text { (crianças } 0-12 \\
\text { anos) }\end{array}$ & Qualitativa & $\begin{array}{l}\text { Mães percebem médicos } \\
\text { como rede de suporte, porém } \\
\text { há resistência a incluir temas } \\
\text { psicossociais }\end{array}$ \\
\hline $\begin{array}{c}\text { Jirasevijinda \& } \\
\text { Brown (2010) }\end{array}$ & $\begin{array}{l}\text { Avaliar método } \\
\text { para abordar } \\
\text { aspecto psicossocial }\end{array}$ & Questionários & 30 residentes & Quantitativa & $\begin{array}{l}\text { Residentes avaliaram que o } \\
\text { programa foi eficiente para } \\
\text { abordar temas psicossociais }\end{array}$ \\
\hline $\begin{array}{l}\text { Kain et al. } \\
\text { (2009) }\end{array}$ & $\begin{array}{l}\text { Analisar a } \\
\text { comunicação } \\
\text { triádica pré- } \\
\text { cirúrgica }\end{array}$ & Videogravação & $\begin{array}{l}60 \text { médicos e } 24 \\
\text { díades (crianças } \\
\text { 2-10 anos) }\end{array}$ & Quantitativa & $\begin{array}{l}\text { Crianças são excluídas } \\
\text { da comunicação e houve } \\
\text { associação entre idade e } \\
\text { interação }\end{array}$ \\
\hline $\begin{array}{l}\text { Kästel et al. } \\
\text { (2011) }\end{array}$ & $\begin{array}{l}\text { Avaliar percepção } \\
\text { de pais sobre } \\
\text { informações }\end{array}$ & Entrevistas & $\begin{array}{c}8 \text { famílias } \\
\text { (crianças } 2 \\
\text { meses-17 anos) }\end{array}$ & Qualitativa & $\begin{array}{c}\text { Pais se adaptam melhor } \\
\text { ao tratamento se suas } \\
\text { necessidades individuais são } \\
\text { atendidas }\end{array}$ \\
\hline $\begin{array}{l}\text { Kemper et al. } \\
\quad(2008)\end{array}$ & $\begin{array}{l}\text { Avaliar viabilidade } \\
\text { de treinamento } \\
\text { on-line }\end{array}$ & $\begin{array}{l}\text { Curso on-line } \\
\text { Questionários }\end{array}$ & 61 pediatras & Quantitativa & $\begin{array}{c}\text { Participantes indicaram maior } \\
\text { habilidade comunicativa após } \\
\text { o curso }\end{array}$ \\
\hline
\end{tabular}




\begin{tabular}{|c|c|c|c|c|c|}
\hline Autores e Ano & Objetivos & $\begin{array}{l}\text { Instrumentos } \\
\text { e Técnicas }\end{array}$ & Participantes & Análise & Principais Resultados \\
\hline $\begin{array}{l}\text { Kiguli et al. } \\
\text { (2011) }\end{array}$ & $\begin{array}{l}\text { Avaliar preferências } \\
\text { comunicativas de } \\
\text { pais }\end{array}$ & Grupos Focais & 24 cuidadores & Qualitativa & $\begin{array}{l}\text { Destaque à necessidade de } \\
\text { suporte social e empatia }\end{array}$ \\
\hline $\begin{array}{l}\text { Lambert et al. } \\
\qquad(2011)\end{array}$ & $\begin{array}{l}\text { Analisar percepção } \\
\text { de pacientes }\end{array}$ & $\begin{array}{l}\text { Observação } \\
\text { direta } \\
\text { Entrevistas }\end{array}$ & $\begin{array}{l}49 \text { pacientes } \\
(6-16 \text { anos })\end{array}$ & Qualitativa & $\begin{array}{c}\text { Pacientes destacaram demanda } \\
\text { por participação, informação } \\
\text { individualizada }\end{array}$ \\
\hline Liu et al. (2007) & $\begin{array}{l}\text { Investigar avaliação } \\
\text { sobre habilidades } \\
\text { de residentes }\end{array}$ & $\begin{array}{l}\text { Questionário } \\
\text { específico }\end{array}$ & 573 cuidadores & Qualitativa & $\begin{array}{l}\text { Principal aspecto destacado foi } \\
\text { a comunicação. A satisfação } \\
\text { com comunicação é relevante }\end{array}$ \\
\hline $\begin{array}{l}\text { Mack et al. } \\
\text { (2006) }\end{array}$ & $\begin{array}{l}\text { Avaliar preferências } \\
\text { de informação }\end{array}$ & Questionários & $\begin{array}{l}194 \text { pais } \\
\text { (crianças } 0-18 \\
\text { anos) e } 20 \\
\text { médicos }\end{array}$ & Qualitativa & $\begin{array}{l}\text { A maioria indicou preferência } \\
\text { por maior quantidade de } \\
\text { informações em números }\end{array}$ \\
\hline $\begin{array}{l}\text { Mangione- } \\
\text { Smith et al. } \\
\quad(2001)\end{array}$ & $\begin{array}{l}\text { Analisar iniciativa } \\
\text { de pais e médicos } \\
\text { em consultas }\end{array}$ & $\begin{array}{l}\text { Questionários } \\
\text { específicos } \\
\text { Audiogravação }\end{array}$ & $\begin{array}{l}10 \text { médicos e } \\
287 \text { pais } \\
\text { (crianças } 2-10 \\
\text { anos) }\end{array}$ & Quantitativa & $\begin{array}{c}\text { Houve pouca inclusão sobre } \\
\text { demanda de medicação. } \\
\text { Associação entre comunicação } \\
\text { e satisfação }\end{array}$ \\
\hline $\begin{array}{l}\text { Märtenson et al. } \\
\qquad(2007)\end{array}$ & $\begin{array}{l}\text { Descrever interação } \\
\text { em consultas }\end{array}$ & $\begin{array}{l}\text { Observação } \\
\text { participante } \\
\text { Dados de } \\
\text { prontuários }\end{array}$ & $\begin{array}{c}28 \text { pacientes }(10- \\
17 \text { anos })\end{array}$ & Qualitativa & $\begin{array}{l}\text { Pacientes interagem sobre } \\
\text { suas vivências e buscam } \\
\text { informações }\end{array}$ \\
\hline $\begin{array}{l}\text { McGraw et al. } \\
\text { (2012) }\end{array}$ & $\begin{array}{l}\text { Avaliar instrumento } \\
\text { para feedback e } \\
\text { satisfação }\end{array}$ & $\begin{array}{l}\text { Paediatric } \\
\text { Carers of } \\
\text { Children } \\
\text { Feedback tool } \\
\text { (PaedCCF) }\end{array}$ & 122 médicos & Quantitativa & $\begin{array}{l}\text { Cuidadores indicaram } \\
\text { satisfação com a comunicação. } \\
\text { Associações com dados } \\
\text { demográficos }\end{array}$ \\
\hline $\begin{array}{l}\text { Miller et al. } \\
\text { (2005) }\end{array}$ & $\begin{array}{c}\text { Avaliar } \\
\text { comunicação sobre } \\
\text { protocolos }\end{array}$ & $\begin{array}{c}\text { Audiogravação } \\
\text { Questionários }\end{array}$ & $\begin{array}{l}127 \text { cuidadores } \\
\text { (crianças } 1-17 \\
\text { anos) }\end{array}$ & Quantitativa & $\begin{array}{l}\text { Cuidadores com escolaridade } \\
\text { e renda mais baixas recebem } \\
\text { menos informações }\end{array}$ \\
\hline $\begin{array}{l}\text { Nestel et al. } \\
\text { (2004) }\end{array}$ & $\begin{array}{l}\text { Avaliar um } \\
\text { workshop sobre } \\
\text { comunicação }\end{array}$ & $\begin{array}{l}\text { Workshop } \\
\text { específico } \\
\text { Questionários }\end{array}$ & 28 pediatras & Mista & $\begin{array}{c}\text { O workshop promoveu } \\
\text { oportunidade para refletir sobre } \\
\text { a comunicação }\end{array}$ \\
\hline $\begin{array}{l}\text { Nova et al. } \\
\text { (2005) }\end{array}$ & $\begin{array}{l}\text { Avaliar a } \\
\text { contribuição da } \\
\text { criança }\end{array}$ & Videogravação & $\begin{array}{l}\text { Dez tríades } \\
\text { paciente }(2-6 \\
\text { anos), médico e } \\
\text { cuidador }\end{array}$ & $\begin{array}{l}\text { Análise } \\
\text { mista }\end{array}$ & $\begin{array}{l}\text { A contribuição da criança } \\
\text { é limitada, mas pacientes } \\
\text { indicaram suas demandas }\end{array}$ \\
\hline $\begin{array}{c}\text { Oliveira \& } \\
\text { Gomes (2004) }\end{array}$ & $\begin{array}{l}\text { Avaliar percepção } \\
\text { de adolescentes }\end{array}$ & Entrevistas & $\begin{array}{l}18 \text { adolescentes } \\
\text { (12-18 anos) }\end{array}$ & Qualitativa & $\begin{array}{l}\text { Pacientes indicam importância } \\
\text { de serem incluídos: mães são } \\
\text { mediadoras }\end{array}$ \\
\hline $\begin{array}{l}\text { Patistea \& } \\
\text { Babatsikou } \\
\quad(2003)\end{array}$ & $\begin{array}{c}\text { Avaliar tipo, } \\
\text { fontes e satisfação } \\
\text { com informações } \\
\text { providas }\end{array}$ & $\begin{array}{l}\text { Entrevistas } \\
\text { Questionário } \\
\text { específico }\end{array}$ & $\begin{array}{l}71 \text { cuidadores de } \\
\text { pacientes (média } \\
8 \text { anos) com } \\
\text { leucemia }\end{array}$ & $\begin{array}{l}\text { Análise } \\
\text { mista }\end{array}$ & $\begin{array}{l}\text { A informação é biomédica e } \\
\text { pais indicam necessidade de } \\
\text { temas psicossociais }\end{array}$ \\
\hline $\begin{array}{l}\text { Périco et al. } \\
\text { (2006) }\end{array}$ & $\begin{array}{c}\text { Investigar } \\
\text { percepção de mães }\end{array}$ & Entrevistas & $\begin{array}{l}12 \text { mães de } \\
\text { crianças }(2-24 \\
\text { meses })\end{array}$ & Qualitativa & $\begin{array}{c}\text { Participantes indicaram } \\
\text { importância de informações } \\
\text { detalhadas }\end{array}$ \\
\hline $\begin{array}{c}\text { Perosa \& } \\
\text { Ranzani }(2008)\end{array}$ & $\begin{array}{l}\text { Avaliar percepção } \\
\text { de médicos }\end{array}$ & $\begin{array}{l}\text { Questionário } \\
\text { específico }\end{array}$ & 53 médicos & Quantitativa & $\begin{array}{l}\text { Criança tem direito às } \\
\text { informações, mas apenas } 30 \% \\
\text { receberam treinamento }\end{array}$ \\
\hline Pinto (2010) & $\begin{array}{l}\text { Comparar } \\
\text { comunicação em } \\
\text { serviços }\end{array}$ & $\begin{array}{l}\text { Videogravação, } \\
\text { entrevista, } \\
\text { observação }\end{array}$ & $\begin{array}{l}12 \text { díades } \\
\text { (crianças } \\
7-11 \text { anos); } 8 \\
\text { pediatras }\end{array}$ & $\begin{array}{l}\text { Análise } \\
\text { mista }\end{array}$ & $\begin{array}{l}\text { No atendimento primário, } \\
\text { houve maior incentivo à } \\
\text { participação }\end{array}$ \\
\hline
\end{tabular}




\begin{tabular}{|c|c|c|c|c|c|}
\hline Autores e Ano & Objetivos & $\begin{array}{l}\text { Instrumentos } \\
\text { e Técnicas }\end{array}$ & Participantes & Análise & Principais Resultados \\
\hline Ranzani (2009) & $\begin{array}{c}\text { Analisar a } \\
\text { percepção de mães }\end{array}$ & Entrevista & $\begin{array}{l}6 \text { mães (filhos } \\
\text { de } 7 \text { meses } \\
\text { a } 16 \text { anos) }\end{array}$ & Qualitativa & $\begin{array}{l}\text { Mães são mediadoras da } \\
\text { comunicação com filhos. } \\
\text { Vínculo facilita comunicação }\end{array}$ \\
\hline $\begin{array}{l}\text { Rider et al. } \\
\quad(2008)\end{array}$ & $\begin{array}{l}\text { Avaliar percepção } \\
\text { de residentes }\end{array}$ & $\begin{array}{l}\text { Questionário } \\
\text { específico }\end{array}$ & 89 residentes & Quantitativa & $\begin{array}{l}\text { Participantes destacaram } \\
\text { habilidades comunicativas, } \\
\text { há pouco treinamento }\end{array}$ \\
\hline $\begin{array}{l}\text { Ringnér et al. } \\
\text { (2010) }\end{array}$ & $\begin{array}{l}\text { Avaliar a percepção } \\
\text { dos pediatras }\end{array}$ & Grupos focais & 20 pediatras & Qualitativa & $\begin{array}{c}\text { Destaque para preferências } \\
\text { individuais e aspectos } \\
\text { dificultadores }\end{array}$ \\
\hline $\begin{array}{l}\text { Schuster et al. } \\
\text { (2000) }\end{array}$ & $\begin{array}{l}\text { Avaliar percepção } \\
\text { de pais sobre } \\
\text { consultas }\end{array}$ & Entrevistas & $\begin{array}{c}2017 \text { pais } \\
\text { (crianças } 0-3 \\
\text { anos) }\end{array}$ & $\begin{array}{l}\text { Análise } \\
\text { mista }\end{array}$ & $\begin{array}{l}\text { Pais indicaram demandas } \\
\text { psicossociais e relação } \\
\text { satisfação-comunicação }\end{array}$ \\
\hline $\begin{array}{l}\text { Scrimin et al. } \\
\qquad(2005)\end{array}$ & $\begin{array}{l}\text { Analisar interação } \\
\text { na comunicação }\end{array}$ & Entrevistas & $\begin{array}{c}21 \text { pais de } \\
\text { crianças (9-192 } \\
\text { meses) }\end{array}$ & Qualitativa & $\begin{array}{l}\text { Fase pós-diagnóstico é crítica, } \\
\text { com sobrecarga emocional }\end{array}$ \\
\hline $\begin{array}{l}\text { Sharma et al. } \\
\text { (2012) }\end{array}$ & $\begin{array}{l}\text { Avaliar percepção } \\
\text { sobre grupo com } \\
\text { alergista }\end{array}$ & $\begin{array}{l}\text { Questionários } \\
\text { específicos }\end{array}$ & $\begin{array}{l}29 \text { pais } \\
\text { (crianças } 1-11 \\
\text { anos) }\end{array}$ & Quantitativa & $\begin{array}{c}\text { Participação diminuiu } \\
\text { ansiedade, melhorou qualidade } \\
\text { de vida }\end{array}$ \\
\hline $\begin{array}{l}\text { Sleath et al. } \\
\text { (2011) }\end{array}$ & $\begin{array}{l}\text { Analisar associação } \\
\text { entre comunicação } \\
\text { e satisfação }\end{array}$ & $\begin{array}{c}\text { Child Satisfaction } \\
\text { Questionnaire } \\
\text { Caregiver } \\
\text { Medical } \\
\text { Interview } \\
\text { Satisfaction }\end{array}$ & $\begin{array}{l}41 \text { médicos e } \\
120 \text { díades } \\
\text { (crianças } 8-16 \\
\text { anos) }\end{array}$ & Quantitativa & $\begin{array}{l}\text { Satisfação de cuidadores } \\
\text { e crianças foi associada à } \\
\text { interação participativa e } \\
\text { estabelecimento de vínculo } \\
\text { pelo médico }\end{array}$ \\
\hline $\begin{array}{l}\text { Sleath et al. } \\
\text { (2012) }\end{array}$ & $\begin{array}{l}\text { Analisar relação } \\
\text { entre comunicação } \\
\text { e adesão }\end{array}$ & $\begin{array}{l}\text { Audiogravação, } \\
\text { Brief Medication } \\
\text { Questionaire }\end{array}$ & $\begin{array}{l}216 \text { crianças } \\
(8-16 \text { anos })\end{array}$ & Quantitativa & $\begin{array}{l}\text { Qualidade da comunicação } \\
\text { influencia níveis de adesão aos } \\
\text { cuidados }\end{array}$ \\
\hline Stivers (2001) & $\begin{array}{l}\text { Analisar seleção } \\
\text { do falante nas } \\
\text { interações }\end{array}$ & $\begin{array}{l}\text { Videogravação } \\
\text { Audiogravação }\end{array}$ & $\begin{array}{l}291 \text { consultas } \\
\text { (crianças } 0-15 \\
\text { anos) }\end{array}$ & Quantitativa & $\begin{array}{l}\text { Houve associação de dados } \\
\text { sociodemográficos da criança } \\
\text { e inserção }\end{array}$ \\
\hline Stivers (2012) & $\begin{array}{l}\text { Analisar variáveis } \\
\text { preditoras da } \\
\text { comunicação }\end{array}$ & Videogravação & $\begin{array}{c}38 \text { pediatras } \\
322 \text { consultas }\end{array}$ & Mista & $\begin{array}{l}\text { Raça, escolaridade da criança e } \\
\text { estilo comunicativo do médico } \\
\text { são associados à interação }\end{array}$ \\
\hline $\begin{array}{l}\text { Stivers \& Majid } \\
\quad(2007)\end{array}$ & $\begin{array}{l}\text { Analisar perguntas } \\
\text { para pacientes }\end{array}$ & Videogravação & $\begin{array}{l}570 \text { consultas e } \\
38 \text { pediatras } \\
\text { (crianças } 6 \\
\text { meses- } 10 \text { anos) }\end{array}$ & Quantitativa & $\begin{array}{c}\text { Fatores como escolaridade e } \\
\text { raça podem estar associados } \\
\text { à quantidade de perguntas às } \\
\text { crianças }\end{array}$ \\
\hline $\begin{array}{l}\text { Swedlund et al. } \\
\text { (2012) }\end{array}$ & $\begin{array}{c}\text { Analisar } \\
\text { associações entre } \\
\text { comunicação e } \\
\text { satisfação }\end{array}$ & $\begin{array}{l}\text { Videogravação } \\
\text { Questionários }\end{array}$ & $\begin{array}{l}8 \text { médicos e } 75 \\
\text { díades (pacientes } \\
\text { 9-16 anos) }\end{array}$ & Quantitativa & $\begin{array}{c}\text { Houve associações } \\
\text { significativas entre a } \\
\text { comunicação e a satisfação de } \\
\text { cuidadores }\end{array}$ \\
\hline $\begin{array}{l}\text { Tates \& } \\
\text { Meeuwesen } \\
(2000)\end{array}$ & $\begin{array}{l}\text { Explorar padrões } \\
\text { de iniciativa } \\
\text { de assuntos em } \\
\text { atendimento }\end{array}$ & Videogravação & $\begin{array}{l}58 \text { pediatras e } \\
106 \text { famílias } \\
\text { (crianças } 4-12 \\
\text { anos) }\end{array}$ & Quantitativa & $\begin{array}{l}\text { A participação infantil vem } \\
\text { aumentando, mas ainda é } \\
\text { restrita e orientada pelos pais e } \\
\text { médicos }\end{array}$ \\
\hline $\begin{array}{l}\text { Tates, Elbers, et } \\
\text { al. (2002) }\end{array}$ & $\begin{array}{l}\text { Analisar interação } \\
\text { e incentivo à } \\
\text { participação da } \\
\text { criança }\end{array}$ & Videogravação & 58 médicos & Mista & $\begin{array}{c}\text { Apesar do direcionamento } \\
\text { médico à criança, } 90 \% \text { das } \\
\text { interações indicaram não } \\
\text { participação }\end{array}$ \\
\hline $\begin{array}{c}\text { Tates, } \\
\text { Meeuwesen } \\
\text { Elbers, et al. } \\
\text { (2002) }\end{array}$ & $\begin{array}{c}\text { Analisar interação } \\
\text { comunicativa em } \\
\text { pediatria }\end{array}$ & Videogravação & 58 médicos & Qualitativa & $\begin{array}{c}\text { Pais e médicos estabelecem um } \\
\text { padrão de comunicação que } \\
\text { exclui o paciente }\end{array}$ \\
\hline
\end{tabular}




\begin{tabular}{|c|c|c|c|c|c|}
\hline Autores e Ano & Objetivos & $\begin{array}{l}\text { Instrumentos } \\
\text { e Técnicas }\end{array}$ & Participantes & Análise & Principais Resultados \\
\hline $\begin{array}{c}\text { Tates, } \\
\text { Meeuwesen } \\
\text { Bensing, et al. } \\
\text { (2002) }\end{array}$ & $\begin{array}{l}\text { Comparar padrões } \\
\text { de comunicação } \\
\text { afetiva e } \\
\text { instrumental }\end{array}$ & Videogravação & $\begin{array}{l}58 \text { médicos e } \\
106 \text { consultas } \\
\text { com crianças } \\
\text { (4-12 anos) }\end{array}$ & Quantitativa & $\begin{array}{c}\text { A interação entre médico e } \\
\text { criança se caracterizou mais } \\
\text { por padrões instrumentais que } \\
\text { afetivos }\end{array}$ \\
\hline $\begin{array}{l}\text { Taylor et al. } \\
\quad(2010)\end{array}$ & $\begin{array}{l}\text { Analisar } \\
\text { participação de } \\
\text { crianças }\end{array}$ & Entrevistas & $\begin{array}{l}20 \text { famílias } \\
\text { (pacientes 7-16 } \\
\text { anos) }\end{array}$ & Qualitativa & $\begin{array}{l}\text { Há necessidade de inclusão } \\
\text { da criança, associada a } \\
\text { características das famílias }\end{array}$ \\
\hline $\begin{array}{l}\text { Vaknin \& Zisk- } \\
\text { Rony (2010) }\end{array}$ & $\begin{array}{l}\text { Analisar percepção } \\
\text { de médicos }\end{array}$ & $\begin{array}{l}\text { Questionários } \\
\text { específicos }\end{array}$ & 143 pediatras & Quantitativa & $\begin{array}{l}\text { Crianças devem ser } \\
\text { incluídas. Interação ocorre } \\
\text { principalmente com } \\
\text { orientações }\end{array}$ \\
\hline $\begin{array}{l}\text { Van Dulmen } \\
\text { (2004) }\end{array}$ & $\begin{array}{l}\text { Avaliar padrões de } \\
\text { comunicação }\end{array}$ & $\begin{array}{l}\text { Videogravação } \\
\text { Questionários }\end{array}$ & $\begin{array}{c}21 \text { médicos } \\
\text { e } 846 \text { díades } \\
\text { (crianças } 5 \text { anos) }\end{array}$ & Mista & $\begin{array}{l}\text { Padrão biopsicossocial em } \\
45 \% \text { das consultas }\end{array}$ \\
\hline $\begin{array}{l}\text { Vatne, } \\
\text { Slaughter, et al. } \\
\text { (2010) }\end{array}$ & $\begin{array}{c}\text { Comparar } \\
\text { compreensão } \\
\text { de sintomas por } \\
\text { crianças }\end{array}$ & Entrevistas & $\begin{array}{l}14 \text { crianças } \\
\text { (7-12 anos) }\end{array}$ & Qualitativa & $\begin{array}{l}\text { Houve conhecimento coerente } \\
\text { da terminologia. Crianças } \\
\text { com câncer indicaram mais } \\
\text { sintomas conhecidos }\end{array}$ \\
\hline $\begin{array}{l}\text { Washington et } \\
\text { al. (2012) }\end{array}$ & $\begin{array}{l}\text { Analisar } \\
\text { comunicação } \\
\text { triádica em } \\
\text { consultas }\end{array}$ & $\begin{array}{l}\text { Audiogravação } \\
\text { Questionários }\end{array}$ & $\begin{array}{l}41 \text { médicos e } \\
296 \text { díades } \\
\text { (pacientes 8-16 } \\
\text { anos) }\end{array}$ & Quantitativa & $\begin{array}{l}\text { Houve focalização frequente } \\
\text { em recomendações de cuidados }\end{array}$ \\
\hline $\begin{array}{l}\text { Wassmer et al. } \\
\qquad(2004)\end{array}$ & $\begin{array}{l}\text { Descrever e } \\
\text { componentes da } \\
\text { comunicação }\end{array}$ & $\begin{array}{l}\text { Questionários } \\
\text { Audiogravação }\end{array}$ & $\begin{array}{l}12 \text { médicos e } 51 \\
\text { díades (crianças } \\
0-14 \text { anos) }\end{array}$ & Quantitativa & $\begin{array}{c}\text { Médicos realizam } 61 \% \text { da } \\
\text { interação, crianças } 4 \% \text {. Tema } \\
84 \% \text { instrumental, } 13 \% \\
\text { afetivo-emocional e } 3 \% \text { social }\end{array}$ \\
\hline $\begin{array}{l}\text { Wildman et al. } \\
\qquad(2004)\end{array}$ & $\begin{array}{l}\text { Avaliar inclusão da } \\
\text { sobrecarga materna } \\
\text { na consulta }\end{array}$ & $\begin{array}{c}\text { Pediatric } \\
\text { Symptom } \\
\text { Checklist e Beck } \\
\text { Depression } \\
\text { Inventory }\end{array}$ & $\begin{array}{l}138 \text { mães e } \\
\text { crianças (4-12 } \\
\text { anos) }\end{array}$ & Quantitativo & $\begin{array}{c}\text { Situação psicossocial das } \\
\text { mães é importante. Discussão } \\
\text { de fatores psicossociais é } \\
\text { multifacetada }\end{array}$ \\
\hline $\begin{array}{l}\text { Wissow et al. } \\
\qquad(2005)\end{array}$ & $\begin{array}{l}\text { Analisar conteúdos } \\
\text { psicossociais }\end{array}$ & Audiogravação & 167 consultas & Quantitativo & $\begin{array}{l}\text { Médicos evitaram discussão de } \\
\text { práticas educativas }\end{array}$ \\
\hline $\begin{array}{l}\text { B. Young, } \\
\text { Dixon-Woods, } \\
\text { Windridge, \& } \\
\text { Heney (2003) }\end{array}$ & $\begin{array}{l}\text { Avaliar percepção } \\
\text { de pais e crianças }\end{array}$ & Entrevistas & $\begin{array}{c}19 \text { pais e } 13 \\
\text { pacientes }(8-17 \\
\text { anos) }\end{array}$ & Qualitativa & $\begin{array}{c}\text { Pais descreveram mediação } \\
\text { e pacientes destacaram } \\
\text { marginalização }\end{array}$ \\
\hline $\begin{array}{l}\text { B. Young et al. } \\
\text { (2010) }\end{array}$ & $\begin{array}{l}\text { Avaliar percepção } \\
\text { de pais sobre } \\
\text { comunicação }\end{array}$ & Entrevistas & $\begin{array}{c}66 \text { pais } \\
\text { (crianças } 1-12 \\
\text { anos) }\end{array}$ & Qualitativa & $\begin{array}{l}\text { Pais destacam inclusão da } \\
\text { criança, mas sua presença } \\
\text { restringe comunicação }\end{array}$ \\
\hline $\begin{array}{l}\text { B. Young et al. } \\
\text { (2011a) }\end{array}$ & $\begin{array}{l}\text { Analisar } \\
\text { informação à } \\
\text { criança }\end{array}$ & Entrevistas & $\begin{array}{c}53 \text { pais } \\
\text { (crianças } 1-12 \\
\text { anos) }\end{array}$ & $\begin{array}{l}\text { Análise } \\
\text { mista }\end{array}$ & $\begin{array}{c}\text { Pais destacam vantagens, mas } \\
\text { nem sempre esta interação é } \\
\text { desejável }\end{array}$ \\
\hline $\begin{array}{l}\text { B. Young et al. } \\
\text { (2011b) }\end{array}$ & $\begin{array}{l}\text { Avaliar percepção } \\
\text { de pais, médicos e } \\
\text { observadores }\end{array}$ & $\begin{array}{l}\text { Audiogravação } \\
\text { Entrevistas }\end{array}$ & $\begin{array}{l}11 \text { médicos e } 50 \\
\text { pais } \\
\text { (crianças } 1-12 \\
\text { anos) }\end{array}$ & Quantitativa & $\begin{array}{c}\text { Pais e médicos percebem } \\
\text { comunicação de forma distinta } \\
\text { e pais destacam colaboração } \\
\text { mútua }\end{array}$ \\
\hline $\begin{array}{l}\text { Zwaanswijk et } \\
\text { al. (2007) }\end{array}$ & $\begin{array}{l}\text { Investigar } \\
\text { preferências de pais } \\
\text { e pacientes }\end{array}$ & Grupos Focais & $\begin{array}{l}11 \text { pais e } 7 \\
\text { crianças } \\
(8-17 \text { anos })\end{array}$ & Qualitativa & $\begin{array}{c}\text { Destaque à importância de } \\
\text { aspectos interpessoais, suporte, } \\
\text { fornecimento de informações e } \\
\text { participação }\end{array}$ \\
\hline $\begin{array}{l}\text { Zwaanswijk et } \\
\text { al. (2011) }\end{array}$ & $\begin{array}{l}\text { Analisar } \\
\text { preferências por } \\
\text { informação }\end{array}$ & $\begin{array}{l}\text { Questionários } \\
\text { específicos }\end{array}$ & $\begin{array}{l}59 \text { pais e } 34 \\
\text { pacientes } \\
(8-16 \text { anos })\end{array}$ & Quantitativa & $\begin{array}{l}\text { Destaque à inclusão da criança, } \\
\text { preferências individuais e } \\
\text { empatia do médico como } \\
\text { fatores relevantes }\end{array}$ \\
\hline
\end{tabular}




\section{Anexo B- Tabela 2: Validação de Questionários e Protocolos Padronizados}

\begin{tabular}{|c|c|c|c|c|}
\hline Autores e Ano & Objetivos & Instrumentos e Técnicas & Participantes & Principais Resultados \\
\hline $\begin{array}{l}\text { Brown \& Krupnik } \\
\text { (2010) }\end{array}$ & $\begin{array}{l}\text { Validação de } \\
\text { instrumento } \\
\text { psicométrico }\end{array}$ & $\begin{array}{l}\text { Vanderbilt Therapeutic } \\
\text { Alliance Scale, Roter } \\
\text { Interaction Analysis System }\end{array}$ & $\begin{array}{l}50 \text { consultas } \\
\text { registradas em } \\
\text { áudio }\end{array}$ & $\begin{array}{l}\text { Interações comunicativas e } \\
\text { aliança terapêutica podem } \\
\text { ser avaliadas a partir de } \\
\text { instrumentos psicométricos }\end{array}$ \\
\hline $\begin{array}{l}\text { Cohen \& Wamboldt } \\
\qquad(2000)\end{array}$ & Avaliar FMSS & $\begin{array}{c}\text { Five Minute Speech Sample } \\
\text { (FMSS) }\end{array}$ & $\begin{array}{l}20 \text { pais (crianças } \\
\text { 6-16 anos) e } \\
\text { pediatras }\end{array}$ & $\begin{array}{l}\text { FMSS permite avaliar a } \\
\text { qualidade da relação entre } \\
\text { cuidadores e médicos }\end{array}$ \\
\hline $\begin{array}{l}\text { Crossley et al. } \\
\qquad(2005)\end{array}$ & $\begin{array}{l}\text { Investigar } \\
\text { instrumento }\end{array}$ & $\begin{array}{l}\text { Análise estatística de } \\
\text { fidedignidade }\end{array}$ & $\begin{array}{c}352 \text { famílias } \\
\text { (crianças } 7-19 \\
\text { anos) e } 62 \text { médicos }\end{array}$ & $\begin{array}{l}\text { Escores elevados para } \\
\text { desempenho geral e mais } \\
\text { baixos para aspectos } \\
\text { familiares }\end{array}$ \\
\hline $\begin{array}{l}\text { Howells et al. } \\
\qquad(2010)\end{array}$ & $\begin{array}{l}\text { Avaliar instrumento } \\
\qquad \text { (PCAT) }\end{array}$ & $\begin{array}{l}\text { Paediatric Consultation } \\
\text { Assessment Tool (PCAT) }\end{array}$ & $\begin{array}{l}188 \text { consultas } \\
\text { (crianças entre } 5 \\
\text { meses e } 15 \text { anos) }\end{array}$ & $\begin{array}{c}\text { O PCAT apresenta } \\
\text { fidedignidade e validade } \\
\text { para observar } \\
\text { a comunicação }\end{array}$ \\
\hline $\begin{array}{l}\text { Moseley et al. } \\
\qquad(2006)\end{array}$ & $\begin{array}{l}\text { Avaliar validade: } \\
\text { Pediatric Trust in } \\
\text { Physician Scale }\end{array}$ & $\begin{array}{c}\text { Análise estatística } \\
\text { de validade }\end{array}$ & $\begin{array}{l}526 \text { pais de } \\
\text { crianças }\end{array}$ & $\begin{array}{c}\text { A escala constitui avaliação } \\
\text { relevante. Fatores } \\
\text { sociodemográficos foram } \\
\text { associados aos escores }\end{array}$ \\
\hline $\begin{array}{l}\text { Rotenberg et al. } \\
\qquad(2008)\end{array}$ & $\begin{array}{l}\text { Avaliar instrumento } \\
\text { psicométrico } \\
\text { e adesão }\end{array}$ & $\begin{array}{c}\text { Children's Trust } \\
\text { in General Physicians Scale } \\
\text { (CTGPS) }\end{array}$ & $\begin{array}{l}326 \text { díades } \\
\text { (crianças } 9 \text { a } 12 \\
\text { anos) }\end{array}$ & $\begin{array}{c}\text { A Escala apresenta } \\
\text { propriedades psicométricas } \\
\text { fidedignas e válidas. Há } \\
\text { associação com adesão } \\
\text { aos cuidados }\end{array}$ \\
\hline Varni et al. (2000) & $\begin{array}{l}\text { Análise fatorial } \\
\text { de instrumento }\end{array}$ & $\begin{array}{c}\text { Pediatric Hematology/ } \\
\text { Oncology Parent Satisfaction } \\
\text { Survey }\end{array}$ & $\begin{array}{l}113 \text { pais de } \\
\text { pacientes } \\
\text { pediátricos }\end{array}$ & $\begin{array}{l}\text { Houve } 4 \text { fatores: satisfação } \\
\text { geral, com comunicação, } \\
\text { com quantidade de } \\
\text { informação e suporte } \\
\text { emocional }\end{array}$ \\
\hline $\begin{array}{l}\text { Vatne, Finset, et al. } \\
\qquad(2010)\end{array}$ & $\begin{array}{l}\text { Avaliar VR-CoDES } \\
\text { para codificar } \\
\text { comunicação }\end{array}$ & $\begin{array}{l}\text { Verona Coding Definitions of } \\
\text { Emotional Sequences (VR- } \\
\text { CoDES) e videogravação }\end{array}$ & $\begin{array}{c}28 \text { consultas de } \\
11 \text { crianças }(6-12 \\
\text { anos })\end{array}$ & $\begin{array}{l}\text { VR-CoDES é confiável } \\
\text { para codificar } \\
\text { comportamentos } \\
\text { comunicativos. Crianças } \\
\text { expressam suas demandas } \\
\text { em consultas }\end{array}$ \\
\hline $\begin{array}{l}\text { Wissow et al. } \\
\qquad(2010)\end{array}$ & $\begin{array}{c}\text { Testar adaptação: } \\
\text { Vanderbilt } \\
\text { Therapeutic } \\
\text { Alliance Scale }\end{array}$ & $\begin{array}{c}\text { Análise fatorial } \\
\text { e codificação de interações } \\
\text { em consultas }\end{array}$ & $\begin{array}{l}243 \text { díades } \\
\text { (crianças } 1-12 \\
\text { anos) }\end{array}$ & $\begin{array}{c}\text { Estrutura fatorial } \\
\text { semelhante a outros } \\
\text { instrumentos, importante } \\
\text { para avaliar comunicação }\end{array}$ \\
\hline
\end{tabular}




\section{Anexo C-Tabela 3: Pesquisas Experimentais e Semi-Experimentais}

\begin{tabular}{|c|c|c|c|c|c|}
\hline $\begin{array}{l}\text { Autores } \\
\text { e Ano }\end{array}$ & Objetivos & $\begin{array}{l}\text { Instrumentos } \\
\text { e Técnicas }\end{array}$ & Participantes & $\begin{array}{l}\text { Delineamento } \\
\text { e Análise }\end{array}$ & Principais Resultados \\
\hline $\begin{array}{l}\text { Ammentorp } \\
\text { et al. (2011) }\end{array}$ & $\begin{array}{c}\text { Avaliar a } \\
\text { eficiência de } \\
\text { intervenção sobre } \\
\text { a comunicação }\end{array}$ & $\begin{array}{c}\text { Videogravação } \\
\text { Questionários } \\
\text { específicos } \\
\text { Palestras e grupos focais }\end{array}$ & $\begin{array}{c}2832 \text { pais e } 32 \\
\text { pediatras }\end{array}$ & $\begin{array}{l}\text { Quantitativa } \\
\text { Quase- } \\
\text { experimental }\end{array}$ & $\begin{array}{l}\text { A intervenção aumentou } \\
\text { a satisfação dos pais }\end{array}$ \\
\hline $\begin{array}{l}\text { Clark et al. } \\
\text { (2000) }\end{array}$ & $\begin{array}{l}\text { Avaliar a eficácia } \\
\text { de procedimento } \\
\text { sobre habilidades } \\
\text { comunicativas }\end{array}$ & $\begin{array}{c}\text { Questionários } \\
\text { Seminários } \\
\text { Entrevistas } \\
\text { Análise de prontuários }\end{array}$ & $\begin{array}{c}74 \text { pediatras e } 637 \\
\text { crianças } \\
(1-12 \text { anos })\end{array}$ & $\begin{array}{l}\text { Quase- } \\
\text { experimental } \\
\text { Quantitativa }\end{array}$ & $\begin{array}{l}\text { Houve mais uso de } \\
\text { habilidades instrumentais } \\
\text { pelo grupo. Pais o } \\
\text { qualificaram melhor e } \\
\text { houve menos internações }\end{array}$ \\
\hline $\begin{array}{l}\text { Cousino } \\
\text { et al. }(2011)\end{array}$ & $\begin{array}{l}\text { Analisar efeitos de } \\
\text { intervenção sobre } \\
\text { a comunicação }\end{array}$ & $\begin{array}{l}\text { Seminários específicos } \\
\text { Audiogravação. Roter } \\
\text { Interaction Analysis } \\
\text { System }\end{array}$ & $\begin{array}{l}42 \text { médicos } \\
59 \text { famílias }\end{array}$ & $\begin{array}{l}\text { Quase- } \\
\text { experimental } \\
\text { Quantitativa }\end{array}$ & $\begin{array}{c}\text { Médicos participantes da } \\
\text { intervenção estabeleceram } \\
\text { melhor rapport }\end{array}$ \\
\hline $\begin{array}{l}\text { Felt \& } \\
\text { O’Connor } \\
(2003)\end{array}$ & $\begin{array}{l}\text { Avaliar influência } \\
\text { de questionário em } \\
\text { consultas }\end{array}$ & $\begin{array}{l}\text { Questionários } \\
\text { específicos } \\
\text { Child Development } \\
\text { Review (CDR) }\end{array}$ & $\begin{array}{l}257 \text { díades } \\
\text { (crianças } 15- \\
47 \text { meses) e } 66 \\
\text { residentes }\end{array}$ & $\begin{array}{l}\text { Quantitativa. } \\
\text { Quase- } \\
\text { experimental }\end{array}$ & $\begin{array}{l}\text { O uso do CDR aumentou } \\
\text { a identificação e } \\
\text { discussão de problemas } \\
\text { comportamentais }\end{array}$ \\
\hline $\begin{array}{l}\text { Harrington } \\
\text { et al. (2007) }\end{array}$ & $\begin{array}{l}\text { Avaliar efeitos de } \\
\text { intervenção sobre } \\
\text { interação }\end{array}$ & $\begin{array}{l}\text { Programa específico } \\
\text { Audiogravação }\end{array}$ & $\begin{array}{l}4 \text { pediatras e } 81 \\
\text { pais }\end{array}$ & $\begin{array}{l}\text { Quantitativa } \\
\text { Quase- } \\
\text { experimental }\end{array}$ & $\begin{array}{l}\text { Médicos no grupo } \\
\text { experimental interagiram } \\
\text { mais com pais }\end{array}$ \\
\hline $\begin{array}{l}\text { Hart et al. } \\
(2006)\end{array}$ & $\begin{array}{l}\text { Avaliar a eficácia } \\
\text { de intervenção } \\
\text { breve sobre a } \\
\text { comunicação em } \\
\text { pediatria }\end{array}$ & $\begin{array}{c}\text { Palestra, role play, } \\
\text { audiogravação } \\
\text { Parent's Perceptions of } \\
\text { Primary Care. Parent } \\
\text { Medical Interview } \\
\text { Satisfaction Scale }\end{array}$ & $\begin{array}{l}28 \text { residentes e } 92 \\
\text { pais (crianças } 0-3 \\
\text { anos) }\end{array}$ & Quan & $\begin{array}{l}\text { Residentes utilizaram mais } \\
\text { habilidades interpessoais } \\
\text { após intervenção. } \\
\text { Cuidadores indicaram } \\
\text { mudanças na interação dos } \\
\text { médicos }\end{array}$ \\
\hline $\begin{array}{l}\text { Hayutin et } \\
\text { al. }(2009)\end{array}$ & $\begin{array}{l}\text { Avaliar efeitos } \\
\text { diferenciais } \\
\text { de dois } \\
\text { procedimentos }\end{array}$ & $\begin{array}{c}\text { Communication } \\
\text { Questionnaire e } \\
\text { Pediatric Symptom } \\
\text { Checklist }\end{array}$ & $\begin{array}{l}174 \text { pais (crianças } \\
\text { 4-16 anos) } \\
\text { e } 12 \text { médicos }\end{array}$ & $\begin{array}{l}\text { Quantitativa } \\
\text { Quase- } \\
\text { experimental }\end{array}$ & $\begin{array}{c}\text { Grupos que responderam o } \\
\text { questionário estabeleceram } \\
\text { melhor comunicação }\end{array}$ \\
\hline $\begin{array}{l}\text { Nikendei et } \\
\text { al. (2011) }\end{array}$ & $\begin{array}{l}\text { Avaliar influência } \\
\text { de programa em } \\
\text { comunicação }\end{array}$ & $\begin{array}{l}\text { Videogravação } \\
\text { Palestras, role play } \\
\text { Questionários } \\
\text { específicos }\end{array}$ & $\begin{array}{l}28 \text { médicos } \\
\text { residentes }\end{array}$ & $\begin{array}{l}\text { Quantitativa. } \\
\text { Experimental: } \\
\text { grupos } \\
\text { randomizados }\end{array}$ & $\begin{array}{l}\text { O grupo intervenção } \\
\text { mostrou melhores } \\
\text { habilidades } \\
\text { e auto-eficácia }\end{array}$ \\
\hline Silva (2000) & $\begin{array}{l}\text { Comparar efeito } \\
\text { de intervenções }\end{array}$ & $\begin{array}{l}\text { Audiogravação } \\
\text { Entrevistas }\end{array}$ & $\begin{array}{l}5 \text { pediatras; } 117 \\
\text { cuidadores } \\
\text { (crianças } 0-5 \text { anos) }\end{array}$ & Análise mista & $\begin{array}{l}\text { Houve mais abordagem } \\
\text { de temas e dúvidas a partir } \\
\text { das intervenções }\end{array}$ \\
\hline $\begin{array}{l}\text { Van Dulmen } \\
\quad \& \text { Holl } \\
(2000)\end{array}$ & $\begin{array}{l}\text { Avaliar eficiência } \\
\text { de intervenção }\end{array}$ & $\begin{array}{l}\text { Workshop breve } \\
\text { Videogravação }\end{array}$ & $\begin{array}{l}21 \text { médicos } \\
\text { e } 608 \text { díades }\end{array}$ & $\begin{array}{l}\text { Quase- } \\
\text { experimental } \\
\text { Quantitativa }\end{array}$ & $\begin{array}{c}\text { Mais abordagem de fatores } \\
\text { psicossociais e contato } \\
\text { visual }\end{array}$ \\
\hline $\begin{array}{l}\text { Wissow et } \\
\text { al. }(2008)\end{array}$ & $\begin{array}{l}\text { Avaliar eficiência } \\
\text { de intervenção } \\
\text { comunicativa }\end{array}$ & $\begin{array}{c}\text { Grupos focais, role play } \\
\text { Strength and Difficulties } \\
\text { Questionnaire, } \\
\text { Physician } \\
\text { Belief Scale, General } \\
\text { Health Questionnaire }\end{array}$ & $\begin{array}{l}58 \text { médicos e } 367 \\
\text { famílias } \\
\text { (crianças 5-16 } \\
\text { anos) }\end{array}$ & $\begin{array}{l}\text { Quantitativa. } \\
\text { Experimental: } \\
\text { grupos } \\
\text { randomizados }\end{array}$ & $\begin{array}{c}\text { Não houve diferenças } \\
\text { entre os grupos em relação } \\
\text { às medidas para crianças, } \\
\text { mas houve para medidas } \\
\text { dos pais }\end{array}$ \\
\hline $\begin{array}{l}\text { Wissow et } \\
\text { al. }(2012)\end{array}$ & $\begin{array}{c}\text { Analisar efeitos } \\
\text { de intervenção e } \\
\text { aspectos preditores } \\
\text { à interação }\end{array}$ & $\begin{array}{l}\text { Grupos focais. Strengths } \\
\text { and Difficulties } \\
\text { Questionnaire. } \\
\text { Physician Belief Scale } \\
\text { e Provider Confidence } \\
\text { Scale }\end{array}$ & $\begin{array}{c}50 \text { médicos } \\
344 \text { famílias } \\
\text { (crianças 5-16 } \\
\text { anos) }\end{array}$ & $\begin{array}{l}\text { Quantitativa. } \\
\text { Experimental }\end{array}$ & $\begin{array}{c}\text { Houve diferença } \\
\text { significativa entre os } \\
\text { grupos. Qualidade da } \\
\text { interação foi associada à } \\
\text { melhoria de sintomas }\end{array}$ \\
\hline
\end{tabular}

